\title{
WYCHODNIE RUD MIEDZI NA TERENIE UKRAINY ZACHODNIEJ JAKO BAZA SUROWCOWA METALURGII KOLOROWEJ W OKRESIE FUNKCJONOWANIA KULTURY TRYPOLSKIEJ ${ }^{1}$
}

\author{
BASSETS OF COPPER ORE IN WESTERN UKRAINE \\ AS A RAW MATERIAL BASE OF COLOR METALLURGY \\ IN THE PERIOD OF TRIPOLYE CULTURE
}

\author{
Viktor I. Klochko \\ Institute of Archaeology Ukrainian Academy of Sciences \\ Geroiv Stalingrade 12, UA $04210 \mathrm{Kiev}$, Ukraine \\ Vjacheslav I. Manichev \\ State Scientific Center of Environmental of Nuclear Geochemistry \\ Palladin Avenue 34, UA $03142 \mathrm{Kiev}$, Ukraine \\ Galina S. Kompanec \\ Institute of Geology Ukrainian Academy of Sciences \\ Jkesj Gonchara 55, UA 01054 Kiev, Ukraine \\ Miron S. Kovalchuk \\ Institute of Geology Ukrainian Academy of Sciences \\ Jkesj Gonchara 55, UA 01054 Kiev, Ukraine
}

\begin{abstract}
The article presents a study of copper ore from western Ukraine aimed at explanation of possibilities of their exploitation for the color metallurgy development during the period of Tripolye culture. It gives a short characteristics of lithological, mineralogical, and geochemical composition of copper ores from the Dneper area, Volhynia, and the Carpathians plateau. It further presents results of chemical and spectral analysis of ore-bearing rocks, evaluation of its current state and potential possibilities of their use in the past.

Based upon a statement that metal objects produced during the existence of the Tripolye culture were made of pure copper two methods of its procurement were considered: (a) from a virgin copper, and (b) from oxygenated copper ore of sedimentary origin in which a small number of admixtures was noticed.
\end{abstract}

The paper shows the potential of studies aimed at explanation of the correlation between contemporary and past copper ores and some copper goods from archaeological sites of the Tarnopol region.

\footnotetext{
' Pracę przygotowano do druku w ramach projektu 1HO1GO5912.
} 
Początki oraz wczesne etapy rozwoju metalurgii miedzi na terenie Ukrainy już od dawna koncentrują uwagę badaczy. Wśród znalezisk archeologicznych pochodzących z tego obszaru najważniejsze i najciekawsze są wyroby metalowe kultury trypolskej - pradziejowe wyroby miedziane z terenu Ukrainy Prawobrzeżnej i Mołdawii.

Dotychczas osiagnięto znaczne sukcesy $w$ dziedzinie klasyfikacji trypolskich wyrobów metalowych (ujawniono ich związek ze spokrewnionymi bałkańskimi i południowokarpackimi ośrodkami kulturowymi). Wykonano dużą ilość badań spektroanalitycznych i metalograficznych ${ }^{2}$.

Do chwili obecnej otwarte pozostaje jednak pytanie o możliwości eksploatacji pokładów rud miedzi, które byłyby źródłem surowcowym do produkcji w pradziejach na terenie Ukrainy. E. Czernych i W. Ryndina uważaja, że miedź w sztabkach i wyroby dostawały się na tereny zamieszkane przez ludność trypolską od sąsiadów z południa. $\mathrm{W}$ związku z tym autorzy są zdania, iż kultura trypolska nie znała metalurgii, a opanowała jedynie obróbkę metali (wytwarzanie wyrobów z surowca importowanego) $)^{3}$. W. Klochko przypuszcza natomiast, że ludność trypolska posiadła wiedzę metalurgiczną i eksploatowała kopalnie rud w strefie Przykarpacia i Wołynia $^{4}$.

Ostatnio archeolodzy i geochemicy Narodowej Akademii Nauk Ukrainy przeprowadzili wspólne badania dotyczące archeologicznych znalezisk wyrobów miedzianych w celu ustalenia pochodzenia ich surowca. Ważną pozycję w tych studiach zajmuje rewizja i sprecyzowanie danych geologicznych oraz geochemicznych o pokładach miedzi rodzimej oraz rud miedzionośnych na terenie Ukrainy. Pierwsze badania geologiczne złóż miedzi na zachodzie Ukrainy przeprowadzili polscy geolodzy, którzy ogólnie scharakteryzowali rudy Wołynia, Naddniestrza i Przykarpacia.

Późniejsze badania wykonali miejscowi geolodzy, precyzując między innymi cechy mineralogiczno-geochemiczne wychodni rud, co pozwoliło ocenić możliwości ich wykorzystania jako bazy surowcowej w okresie funkcjonowania kultury trypolskiej, a także w późniejszych epokach historycznych. Pośród wymienionych wyżej wychodni rud słabo zbadany jest rejon znacznej mineralizacji miedzionośnej w obrębie Zakarpackiego Obwodu Ukrainy, którego charakterystyka zostanie podana niżej.

Należy nadmienić, iż kwestia możliwości wykorzystania obecności rud miedzi na terenie Ukrainy zachodniej do produkcji metali kolorowych w dalekiej przeszłości musi być rozpatrywana na innej płaszczyźnie niż rozwiązywane przez geologów zagadnienie bazy surowcowej dla potrzeb współczesnego przemysłu. Wydaje się, że dawni górnicy nie posiadali wiedzy o składzie mineralnym rud miedzionośnych. Głównym kryterium obecności złóż miedzi dla ludności pradziejowej mogło być

\footnotetext{
${ }^{2}$ Czernykh 1966; Ryndina 1971; 1998.

${ }^{3}$ Czernykh 1966, s. 143 ; 1978, s. 388; 1989, s. 1430; Ryndina 1971, s. 142; 1998, s. 16-18.

${ }^{4}$ Klochko 1994, s. 96-132.
} 
zielone zabarwienie (o różnych odcieniach), charakterystyczne dla stref utleniania, rozpoznawane przez obecność malachitu, rzadziej azurytu.

Porównanie wyników analizy spektralnej utlenionych i nieutlenionych skał zawierających miedź o różnym składzie litologicznym świadczy, iż skały utlenione mają wzbogacony koncentrat naturalny. Właśnie ten rodzaj skał, z dużą zawartością malachitu, był dla dawnych wytwórców ważnym surowcem, szczególnie w wypadku osadowych skał miedzionośnych. Okoliczność ta zmusza współczesnego badacza-geologa do zwrócenia szczególnej uwagi na geochemię utlenionych skał miedzionośnych. Przeprowadzone w 1999 roku badania terenowe dowodzą, iż dość trudno znaleźć w odsłonięciach naturalnych skały z cechami utlenionych siarczanów miedzi. Potwierdzają to geolodzy ,przemysłowi”, według których jeszcze 30-40 lat temu dość często można było zauważyć w odsłonięciach naturalnych strefy z rudą utleniona. Na przykład w okolicy miejscowości Jabłonów można było napotkać skały w znacznym stopniu zmalachityzowane, $\mathrm{z}$ wielkimi wrostkami miedzi rodzimej. Obecnie brak w tych odsłonięciach nie tylko miedzi rodzimej, ale i nacieków malachitu, chociaż same odsłonięcia częściowo się zachowały. Jednym z powodów ich zaniku mogła być dynamika procesów naturalnych, w znacznym stopniu wpływająca na ukształtowanie terenu nawet w okresie ostatniego pięciolecia (rozmycie, akumulacja itp.). Dlatego też podczas prac terenowych i doboru materiału skalnego zwracano uwage przede wszystkim na skały utlenione, a w wypadku ich nieobecności - na nieutlenione. Wyniki nowych badań geologiczno-geochemicznych oraz uwzględnienie danych $z$ badań dotychczasowych pozwalają scharakteryzować podstawowe cechy wychodni rud miedzi Ukrainy zachodniej:

I. Naddniestrzańskie wychodnie rud miedzi występują w granicach płyty Wołyńsko-Podolskiej, zachodniej części Tarczy Ukraińskiej i wschodniej części Obniżenia Halicko-Wołyńskiego. W ujęciu fizjograficznym odpowiada to Wyżynie Podolskiej, która jest działem wodnym Dniestru i południowego Bugu. W części naddniestrzańskiej głębokość rozczłonkowania erozyjnego sięga $200 \mathrm{~m}$. Można tu zaobserwować doliny kanionopodobne (jary) Dniestru i jego dopływów. Czwartorzędowe warstwy osadowe nakrywają teren potężną pokrywą w postaci szarych i szarobrunatnych iłów, warstw aluwialnych, a także lessów i lessowych iłów piaszczystych na dawnych terasach Dniestru i jego dopływów. Właśnie w okresie czwartorzędu powstają tu najstarsze osiedla ludzkie, których pozostałości napotyka się w deluwialno-proluwialnych osadach Naddniestrza.

W płaszczyźnie tektonicznej rudy miedzi występują w południowej części wołyńsko-podolskiego krańca Platformy Wschodnioeuropejskiej, w pobliżu Zapadliska Przykarpackiego. System uskoków, ograniczający odrębne bloki, rozciagga się w kierunku południowym, północno-zachodnim i północno-wschodnim. W profilu stratygraficznym strefa miedzionośna występuje w warstwie dewonu dolnego, co można zaobserwować na brzegach Dniestru i jego dopływów. Miąższość dewonu dolnego wynosi tu około $500 \mathrm{~m}$. Warstwa ta występuje w formie czerwonych osadów te- 


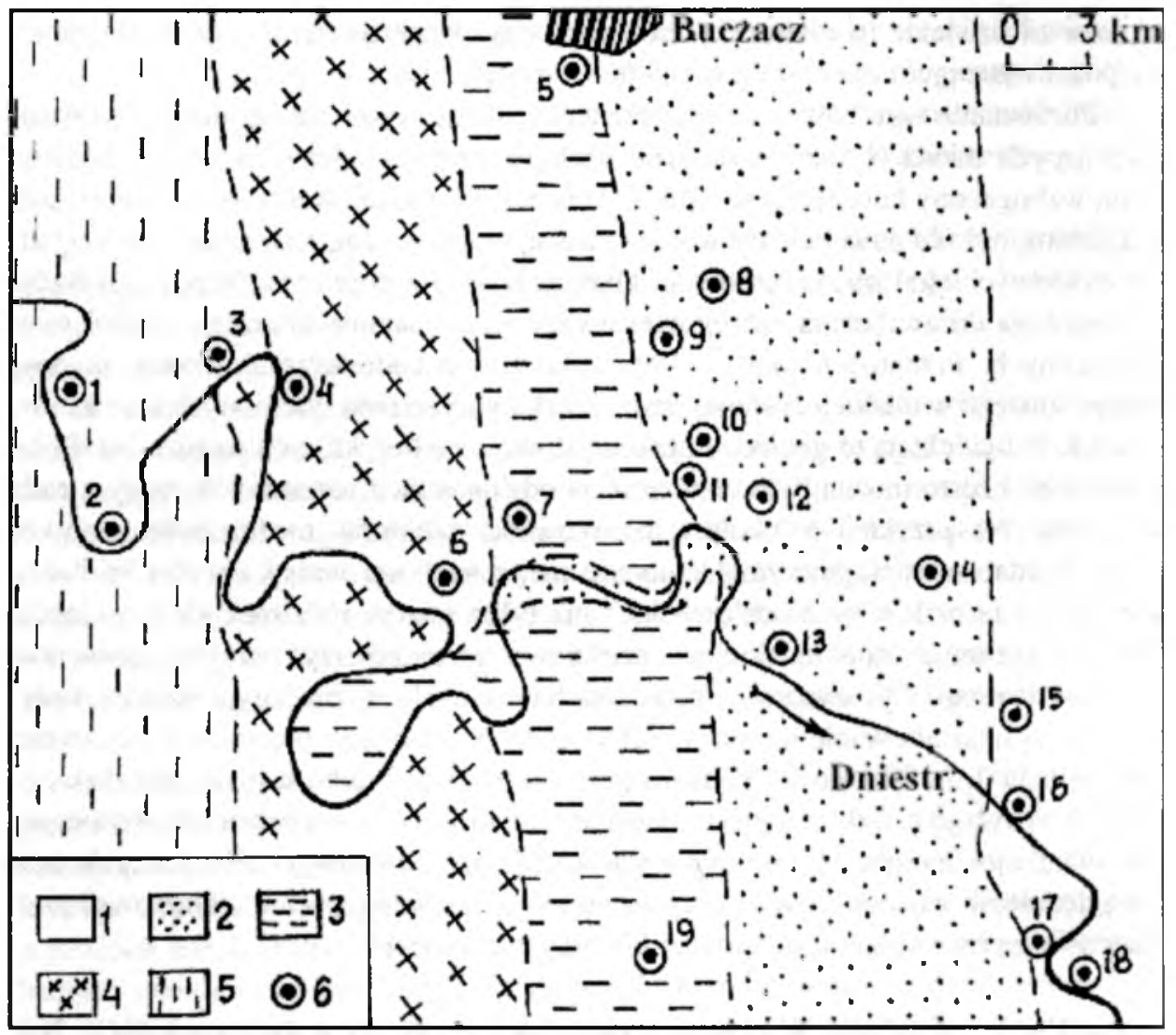

Ryc. 1. Schematyczna mapa geologiczna z odsłonięciami rud miedzi dewonu dolnego na terenie Naddniestrza (podział stratygraficzny wg V. Narbutas 1984) Rys. V. Manichev

Horyzonty dewonu: 1 - ostrejski, 2 - styński, 3 - wyzyłowski, 4 - jazłowiecki, 5 - ustecki.

Wychodnie skał miedzionośnych na odcinkach: 1 - Wystria, 2 - Dołyna, 3 - Styhła, 4 - Stenka, 5 - Buczacz, 6 - Wozyłów, 7 - Kostelniki, 8 - Nowosiłki, 9 - Duliby, 10 - Żybrody, 11 - Beremiana, 12 - Chmielowa, 13 - Lytiacze, 14 - Sadki, 15 - Czerwonograd, 16 - Usteczko, 17 - Horodok, 18 - Iwane-Zołote, 19 - Raszków

Fig. 1. Diagrammatic geological map with copper ore outcrops of Prydnestrovie Lower Devonian (stratigraphic topography by V. Narbutas 1984). By V. Manichev

rygenicznych i odpowiada serii dniestrzańskiej w granicach warstw praskich i emskich. Poniżej złoża te przekształcają się w warstwy lochkowskie, w obrębie których wydziela się szereg horyzontów: chmielewski, usteczkowski, iwaniewski, czortkowski $^{5}$. Zgodnie ze schematem stratygraficznym ${ }^{6}$ wystapienia rud miedzi pojawiają się w granicach horyzontów: czortkowskiego, jazłowieckiego, wozymowskiego, styńskiego i ostrejskiego. Osady serii dniestrzańskiej rozciagają się w kie-

${ }^{5}$ Geologicheskaya istoriya, s. 199.

${ }^{6}$ Narbutas 1984, s. 136. 
runku południowo-zachodnim od Tarnopola do linii Halicz - Czerniowce. Na tym obszarze głębokość występowania dewonu dolnego waha się od 0 do $40 \mathrm{~m}$ na lewym brzegu Dniestru i nieco więcej na prawym. W odsłonięciach naturalnych $\mathrm{z}$ reguły obecne są odrębne części dewonu dolnego.

Po raz pierwszy wychodnie rud miedzi na obszarze Naddniestrza zbadane zostały w 1936 roku przez geologów z Polskiego Instytutu Geologicznego. Następnie badania prowadzili T. Nikulina (1949), A. Lurje (1962), L. Birjuliwa (1963), D. Chruszczow, H. Kompanec (1985-1986). Na tym terenie stwierdzono ponad 20 wychodni skał rudonośnych (ryc. 1), w niektórych przypadkach z podwyższona mineralizacją ołowiową. Ogólna powierzchnia objętego badaniami terytorium wynosi około $600 \mathrm{~km}^{2}$. Złoża zawierają skały złożone z piaskowców (do 23\%), mułowców (do 37\%) i iłowców (do 40\%). Charakterystyczna jest tu niejednolitość miąższości oraz składu w przebiegu podłużnym i poprzecznym warstw. Częste są tu wyklinowania i zastapienia facjalne jednych odmian drugimi.

Wszystkie znane ślady rud odpowiadają kilku nawarstwieniom skał szarych występujących wśród warstw czerwonych. Miąższość rudonośnych nawarstwień na powierzchni zalegania jest niejednolita. Składają się one głównie ze skał jasnoszarych i szarych, dosyć często gruboławicowych piaskowców kwarcowych. Razem z nimi pojawiają się soczewki ciemnoszarych mułowców i iłowców. Powierzchnia występowania rud miedzi w obrębie każdego z horyzontów charakteryzuje się płytkością. Szare piaskowce miedzionośne pochodzenia aluwialnego występują w postaci soczewek. Dosyć często w piaskowcach widoczne jest jednokierunkowe warstwowanie skośne.

Skład petrograficzny szarych piaskowców i czerwonych mułowców jest podobny - różnią się one tylko barwa.

Mułowce i iłowce występują jako wyklinowujące się soczewki o małej miąższości, zawierające na płaszczyznach warstwowania wrostki organiczne o czarnej barwie. Wrostki te są drobnoziarniste, zawierają siarczki miedzi, ołowiu, żelaza i występują w postaci chalkozynu, chalkopirytu, galeny i pirytu. W niektórych skałach siarczany miedzi i ołowiu koncentrują się w pobliżu resztek organicznych.

Odsłonięcia rud miedzi obserwuje się w największych masywnych piaskowcach kwarcytowych, ale w znacznie mniejszych ilościach. Występują tu one w formie rzadkich wrostków, małych rozmiarów soczewek i nalotów kalcytu na płaszczyźnie pęknięć. Miąższość pojedynczych soczewek skał ilastych wynosi 1-2 cm, natomiast miąższość ogólna - do 1,5 m, a długość do 100-150 m. Reprezentowane są one przeważnie przez iłowce $\mathrm{z}$ nierównomiernymi wtrętami rudnymi, które zawieraja 7-8\% miedzi, przy średniej zawartości w przedziale $1,0-1,5 \%$.

Piaskowce, a także mułowce i iłowce $z$ różnych odsłonięć, tylko nieznacznie różnią się składem mineralnym, cechami strukturalno-teksturalnymi oraz stopniem segregacji i obtoczenia materiału plastycznego. 
Tabela 1

Wyniki analizy chemicznej skał miedzionośnych Naddniestrza (\%)

Table 1

The Prydnestrovie Devonian cuprous rocks chemical analysis results (\%)

\begin{tabular}{|c|c|c|c|c|c|c|}
\hline \multirow[b]{2}{*}{$\begin{array}{l}\text { Zwiazek } \\
\text { chemiczny }\end{array}$} & \multicolumn{6}{|c|}{ Nr wzorca mineralnego, facja, miejsce pobrania próby } \\
\hline & $\begin{array}{c}\text { próba D-51 } \\
\text { piaskowiec- } \\
\text { koryto rzeczne } \\
\text { obszar M-12 } \\
\text { lewy brzeg } \\
\text { rzeki Jangorik }\end{array}$ & $\begin{array}{c}\text { próba D-66 } \\
\text { piaskowiec } \\
\text { szary - koryto } \\
\text { rzeczne } \\
\text { obszar M-18 } \\
\text { lewy brzeg } \\
\text { rzeki Dniestr }\end{array}$ & $\begin{array}{c}\text { próba D-68 } \\
\text { piaskowiec } \\
\text { szary } \\
\text { obszar M-18 } \\
\text { lewy brzeg } \\
\text { rzeki Dniestr }\end{array}$ & $\begin{array}{c}\text { próba D-70 } \\
\text { piaskowiec } \\
\text { szary - koryto } \\
\text { rzeczne } \\
\text { obszar M-18 } \\
\text { lewy brzeg } \\
\text { rzeki Dniestr }\end{array}$ & $\begin{array}{c}\text { próba D-71 } \\
\text { piaskowiec } \\
\text { szary - koryto } \\
\text { rzeczne } \\
\text { obszar M-18 } \\
\text { lewy brzeg } \\
\text { rzeki Dniestr }\end{array}$ & $\begin{array}{c}\text { próba D-96 } \\
\text { piaskowiec } \\
\text { szary - koryto } \\
\text { rzeczne } \\
\text { obszar M-25 } \\
\text { lewy brzeg } \\
\text { rzeki Dżurin }\end{array}$ \\
\hline $\mathrm{SiO}_{2}$ & 86,32 & 88,80 & 86,64 & 85,96 & 72,40 & 86,88 \\
\hline $\mathrm{TiO}_{2}$ & 0,32 & 0,21 & 0,28 & 0,39 & 0,74 & 0,47 \\
\hline $\mathrm{Al}_{2} \mathrm{O}_{3}$ & 5,17 & 4,00 & 4,89 & 6,75 & 10,93 & 5,11 \\
\hline $\mathrm{Fe}_{2} \mathrm{O}_{3}$ & 1,25 & 0,55 & 0,9 & 0,87 & 1,85 & 0,95 \\
\hline $\mathrm{CaO}$ & 1,37 & 1,49 & 1,16 & 0,57 & 0,60 & 0,46 \\
\hline $\mathrm{MgO}$ & 1,14 & 0,97 & 3,07 & 1,14 & 5,60 & 1,05 \\
\hline $\mathrm{K}_{2} \mathrm{O}$ & 0,48 & 0,61 & 0,70 & 1,02 & 2,00 & 0,80 \\
\hline $\mathrm{Na}_{2} \mathrm{O}$ & 0,98 & 0,76 & 0,70 & 0,90 & 0,92 & 0,76 \\
\hline $\mathrm{FeO}$ & & & & & & \\
\hline $\mathrm{MnO}$ & 0,08 & 0,11 & 0,08 & ślad & ślad & 0,22 \\
\hline $\begin{array}{l}\mathrm{P}_{2} \mathrm{O}_{5} \\
\text { strata przy }\end{array}$ & 0,05 & 0,05 & 0,11 & 0,09 & 0,09 & 0,06 \\
\hline $\begin{array}{l}\text { nagrzewaniu } \\
\mathrm{SO}_{3}\end{array}$ & 1,47 & 1,11 & 0,61 & 1,04 & 2,57 & 1,64 \\
\hline$\Sigma$ & 99,57 & 100,17 & 100,41 & 100,10 & 100,31 & 100,09 \\
\hline $\begin{array}{l}S_{\text {ogóny }} \\
S\end{array}$ & ślad & ślad & ślad & ślad & ślad & ślad \\
\hline $\mathrm{C}_{\text {ogólny }}$ & 0,09 & 0,14 & 0,13 & & 0,64 & 0,14 \\
\hline $\begin{array}{l}\mathrm{CO}_{2 \text { kartonatny }} \\
\mathrm{C}_{\text {organiczny }} \\
\mathrm{SiO}_{2}\end{array}$ & 0,44 & 0,71 & 0,68 & 0,62 & 0,03 & 0,22 \\
\hline $\mathrm{CuO}$ & 0,34 & 0,36 & 0,34 & 0,39 & 0,88 & 1,03 \\
\hline $\mathrm{H}_{2} \mathrm{O}$ & 0,07 & 0,30 & 0,12 & 0,36 & 1,06 & 0,30 \\
\hline
\end{tabular}

Piaskowce występują często $\mathrm{w}$ odsłonięciach miedzionośnych, których miąższość waha się od 0,1 do $6 \mathrm{~m}$. $Z$ reguły są to skały drobnoziarniste o szarym i czerwonym zabarwieniu, czasem $\mathrm{z}$ naciekami malachitu na powierzchni (fot. 2). W składzie mineralnym dominuje kwarc (75-90\%). Występują tu także skalenie (mikroklin, oligoklaz, ortoklaz) oraz mika w postaci drobnych łusek muskowitu, biotytu, a także chloryt.

Materiał klastyczny zajmuje nieznaczną objętość; występują tu okruchy skał ilastych, krzemionkowych, łupków, a niekiedy skał efuzywnych. Dominuje spoiwo 
krzemionkowe, kalcytowe, ilasto-żelaziste i marglowe. Wśród nieznacznej domieszki mineralów akcesorycznych stwierdzone zostały pojedyncze ziarna cyrkonu, rutylu, turmałinu, granatu, spineli, hematytu, leukoksenu.

Mułowce występują najczęściej w przeławiceniach, gdzie ich objętość wynosi do 40-50\% miąższości ogólnej. Posiadają one barwę czerwono-brunatną, szara, zielono-szara, plamistą. Pod względem składu mineralnego odpowiadają one mułowcom kwarcowym (75-90\%), z niewielką domieszką (7\%) skaleni i minerałów grupy mik (muskowit, biotyt) (do 15\%). W matriksie ilastym stwierdzono głównie montmorillonit i hydromiki. Mineraly autogeniczne reprezentowane są przez kwarc, hydrogetyt, chalcedon, baryt oraz minerały węglanowe. Zestaw minerałów akcesorycznych na ogół odpowiada zestawowi skał piaszczystych.

Iłowce mają barwę szarą, czerwonawo-brunatną, przypominają czasem łupki o składzie mikowym. Miąższość warstw waha się od 0,5 do $4 \mathrm{~m}$. Wśród minerałów występują domieszki (do 5-10\%) o frakcji mułowcowej. Minerały o tej frakcji stanowią $85-90 \%$, odnotowano wśród nich hydromiki, biotyt, chloryt, a także kwarc i skalenie. Skład chemiczny minerałów akcesorycznych i autogenicznych jest zbieżny ze składem chemicznym piaskowców i mułowców.

W tabeli 1 przedstawiono skład chemiczny skał kompleksu stryjskiego. Wyniki analizy chemicznej wskazały na zawartość $\mathrm{SiO}_{2} \mathrm{rzędu} \mathrm{89 \% ,} \mathrm{CaO} 12 \%, \mathrm{MgO} 3,6 \%$, $\mathrm{FeO} z$ reguły przewyższa $\mathrm{Fe}_{2} \mathrm{O}_{3}$ i wynosi $1,3 \%$. Zwraca tu uwage jednolitość składu chemicznego piaskowców różnych typów facjalnych, w przekroju oraz powierzchni zalegania.

W ilastych piaskowcach miedzionośnych zawartość $\mathrm{SjO}_{2}$ nie przekracza $68 \%$, przy wartości minimalnej $54 \%$, a $\mathrm{Al}_{2} \mathrm{O}_{3}$ waha się nieznacznie w przedziale $0,99-1,24 \%$. Skład chemiczny skał mieszanych jest podobny do skladu skał piaszczystych. Iły miedzionośne zawierają około $0,8 \% \mathrm{TiO}_{2} ; 2,7 \% \mathrm{~K}_{2} \mathrm{O} ; 0,65 \% \mathrm{Na}_{2} \mathrm{O}$; $0,11 \% \mathrm{P}_{2} \mathrm{O}$. Zawartość $\mathrm{CuO}$ zmienia się w przedziale wartości $0,005-0,4 \%$. Skład chemiczny iłowców nie różni się w sposób istotny od składu chemicznego mułowców dolnostebnickiego kompleksu Przykarpacia, z pewnymi odstępstwami (na przykład zawartość $\mathrm{MnO}$ jest dwukrotnie mniejsza, a $\mathrm{CaO}$ dziesięciokrotnie, natomiast $\mathrm{K}_{2} \mathrm{O}$ jest o połowę więcej).

$\mathrm{Na}$ obszarze naddniestrzańskiej strefy występowania rud miedzi większość wychodni znajduje się przeważnie na lewym brzegu rzeki. Na prawym brzegu zauważono jednak znaczne ślady rud w rejonie miejscowości Raszków. Do najznaczniejszych zaliczyć można wychodnie skał rudonośnych w rejonach miejscowości: Semakowce, Usteczko, Iwane-Zołote (fot. 1), Łytiacze, Chmielowa, Żybrody, Horodnica, Czerwonograd, Szuturlynce. Maksymalne ilości Cu w piaskowcach (miejscami do $18 \%$ ) odnotowali polscy geolodzy w rejonie miejscowości Iwane-Zołote. Miąższość warstwy rudonośnej wychodni Semakowce wynosi $2 \mathrm{~m}$, a długość $350 \mathrm{~m}$. Zawartość Cu w mułowcach nie przekracza 0,5\% i występuje w formie malachitu. W wychodni Szuturlynce miąższość mułowców i piaskowców zawierających $\mathrm{Cu}$ 
wynosi około 6-7 m. Naloty malachitu są tu oznaką rozpoznawczą obecności $\mathrm{Cu}$, której zawartość osiagga 1\%. W miejscowości Iwane-Zołote piaskowce i iłowce zawierają rudy $\mathrm{Cu}$, na co wskazuje obecność malachitu i azurytu. Analiza mineralogiczna ujawniła natomiast występowanie chalkozynu. Maksymalna zawartość $\mathrm{Cu}$ w piaskowcach wynosi około $8 \%$, a minimalna około $0,3 \%$.

Wychodnia Łytiacze charakteryzuje się obecnością piaskowców szarych i iłowców o ogólnej miąższości do $3700 \mathrm{~m}$. Odsłonięcia rud miedzi spotyka się w różnych wychodniach w postaci malachitu na płaszczyznach nawarstwienia, w formie nalotów i wrostków. Przy znacznej rozciągłości warstwy rudonośnej (do 1 km) zawartość miedzi nie przekracza $0,5 \%$. Dostrzega się tu podwyższoną ilość ołowiu $(0,3 \%)$; niekiedy oprócz malachitu obecny jest również tenoryt.

W wychodni Chmielowa występują szare piaskowce i mułowce o miąższości do $1,5 \mathrm{~m}$. Zawartość minerałów $\mathrm{Cu}$ - malachitu i azurytu - jest tu dość niska i wynosi nie więcej niż $0,2 \%$.

W miejscowości Żnibrody, położonej na zboczu głębokiej doliny, odsłonięcie skalne rozciaga się na długości $0,5 \mathrm{~km}$. Występują tu piaskowce szare i czerwonawe, mułowce i iłowce. Cu pojawia się tutaj w postaci malachitu, nie przekraczając setnych części procenta - tylko w pojedynczych wychodniach wzrasta ona do $7 \%$.

Wychodnia Usteczko uznana jest za najbogatszą w $\mathrm{Cu}$. Występują tu piaskowce o zabarwieniu jasnoszarym i różowo-brunatnym. Ich miąższość waha się od 2 do $5 \mathrm{~m}$, a rozciagłość do $1,5 \mathrm{~km}$. W tej wychodni rudnej spotyka się malachit, azuryt, chalkozyn i bornit. Zawartość Cu w skałach stanowi $2,4 \%$, wynosząc średnio 0,54\%. Razem z siarczanami występuje tu galena i sfaleryt. W rzadkich soczewkach iłowców i mułowców maksima zawartości mogą wzrastać do 6\%, przy średniej zawartości 2,5\%. W rudzie miedzionośnej obserwuje się $\mathrm{Pb}$ w ilościach do 7\% i Ag do $0,005 \%$.

Głównymi minerałami miedzi są chalkozyn, chalkopiryt, bornit, malachit, kowelin i azuryt. Oprócz nich szeroko rozpowszechnione są: minerały $\mathrm{Pb}$ - galena, i zawierający $\mathrm{Fe}$ - piryt.

Chalkozyn $\left(\mathbf{C u}_{2} \mathbf{S}\right)$ występuje częściej w piaskowcach, mułowcach i iłowcach, tworząc wrostki o rozmiarach do $2 \mathrm{~mm}$, soczewki i żyłki, a także wtrącenia w formie spoiwa rozmieszczonego między ziarnami materiału klastycznego. Chalkozyn jest tu obecny w postaci ziaren o okragłej oraz nieregularnej formie, średnicy od $0,006-0,03$ do $0,3 \mathrm{~mm}$. Niekiedy tworzy on w pirycie sieć gęstych żyłek. W piaskowcach miedzionośnych $\mathrm{w}$ miejscowości Usteczko można niekiedy zauważyć występowanie zamiast chalkopirytu chalkozynu, który zawiera do $70 \% \mathrm{Cu}, 17 \% \mathrm{~S}$, $0,20 \% \mathrm{Fe}$ i $0,30 \% \mathrm{~Pb}$. W rzadkich przypadkach chalkozyn ma postać konkrecji pokrytych warstewką malachitową, w pęknięciach, w których występuje bornit.

Chalkopiryt $\left(\mathrm{CuFeS}_{2}\right)$ pojawia się najczęściej w odsłonięciach rud w miejscowości Raszków, gdzie występuje w postaci kryształów o wielkości 1-2 mm, w paragenezie $z$ kalcytem. Minerał ten spotyka się w skałach piaszczystych $w$ postaci zia- 
ren o wielkości do $0,3 \mathrm{~mm}$, chaotycznie rozproszonych w spoiwie. Brzegi ziaren sa nierówne; w pęknięciach chalkopiryt występuje czasami zamiast chalkozynu. Oprócz miedzi chalkozyn zawiera Fe oraz nieznaczną domieszkę Ni i Mg.

Bornit $\left(\mathrm{Cu}_{5} \mathrm{FeS}_{4}\right)$ i kowelin (CuS) obecnie pojawiają się rzadziej. Bornit formuje drobne ziarna reliktowe albo nieciagłe otoczki. Ziarna osiagają wielkość około $0,1 \mathrm{~mm}$. Minerał ten występuje głównie wśród chalkozynu i kowelinu, rzadziej razem $\mathrm{z}$ galeną $\mathrm{i}$ chalkopirytem. Kowelin obecny jest w postaci bardzo drobnych ziaren o nieregularnej formie.

Malachit $\left(\mathrm{Cu}_{2} \mathrm{CO}_{3} * \mathbf{2 H}_{2} \mathrm{O}\right)$ i azuryt $\left(\mathrm{Cu}_{3}\left[\mathrm{CO}_{3} \mathrm{OH}\right]_{2}\right)$ są minerałami wtórnymi, które powstały przez utlenienie pierwotnych siarczanowych minerałów $\mathrm{Cu}$, już po uformowaniu się skał zawierających rudę. Malachit tworzy nagromadzenia o zielonej barwie, które z reguły pojawiają się na płaszczyznach warstwowania skał miedzionośnych, szczególnie wzbogaconych o substancje organiczne. Minerał ten występuje w postaci warstw, skorup, wrostków w spoiwie piaskowców (fot. 3b), igieł albo agregatów promienisto-włóknistych. W jego skład wchodzi do $53 \% \mathrm{CuO}$, $1,46 \% \mathrm{Fe}_{2} \mathrm{O}_{3}$ i $3 \% \mathrm{Al}_{2} \mathrm{O}_{3}$.

Azuryt spotykany jest rzadziej, przede wszystkim w piaskowcach. Minerał ten formuje warstewki, drobnokrystaliczne i ziemiste skupiska na powierzchni piaskowców, mułowców i iłowców. Zawartość $\mathrm{CuO}$ w tych złożach ocenia się na 45\%.

Galena (PbS) obecna jest w żyłkach rudnych, często w paragenezie $\mathrm{z}$ chalkopirytem (wychodnia Raszków). Są to zazwyczaj drobne, rozproszone wrostki o rozmiarach ziaren w przedziale od 0,2 do $10 \mathrm{~mm}$ i zawartości do $2 \%$, co powoduje zwiększenie zawartości ołowiu $\mathrm{w}$ skałach. W rudach miedzi $\mathrm{w}$ miejscowościach Łytiacze i Horodnica galena tworzy soczewki o długości do $10 \mathrm{~cm}$ i szerokości $0,5 \mathrm{~cm}$.

Piryt $\left(\mathrm{FeS}_{2}\right)$ jest szeroko rozpowszechniony w skałach dewonu, szczególnie w mułowcach i iłowcach, w formie drobnych, ale obficie występujących wrostków, a w rejonie miejscowości Raszków obecny jest także w piaskowcach razem z galeną i chalkopirytem.

Według danych E. Lazarenki ${ }^{7}$ w niektórych wąwozach i na zboczach dolin rzecznych można zauważyć $w$ nieutlenionych skałach rudnych tenoryt i kupryt $\left(\mathrm{Cu}_{2} \mathrm{O}\right)$.

Wyniki analizy spektralnej skal o zróżnicowanym składzie litologicznym zawierających rudę $\mathrm{Cu}$ wskazują klarkowe zawartości dla większości składników (tab. 2). Najniższe zawartości (prawie trzykrotnie niższe od klarkowych) odnotowuje się dla Sn i Cr. Natomiast zawartość miedzi wzrasta pięciokrotnie, a baru dziesięciokrotnie. Maksymalną zawartość $\mathrm{Cu}, \mathrm{V}$, Ni i La obserwuje się w mułowcach rudnych; $\mathrm{Cr}$ i Co - w iłowcach rudnych, a Mn i Ba - w piaskowcach. Praktycznie nie obserwuje się $\mathrm{Sc}, \mathrm{Hf}, \mathrm{Re}, \mathrm{Hg}$ oraz Ge. Oprócz Cu i Pb skały te charakteryzują się wyższą zawartością Y $(0,5-0,8 \%$ w pobliżu miejscowości Usteczko). Dostrzega się wzajemny zwią-

${ }^{7}$ Lazarenko, Srebrodolskiy 1969, s. 346. 
Tabela 2

Wyniki analizy spektralnej skał miedzionośnych Naddniestrza (\%)

Table 2

The Prydnestrovie cuprous rocks spectrum analysis results (\%)

\begin{tabular}{|l|l|l|l|l|l|l|l|l|l|l|}
\hline $\begin{array}{l}\text { Pierwiastki } \\
\text { chemiczne }\end{array}$ & Nr 1 & Nr 2 & Nr 3 & Nr 4 & Nr 5 & Nr 6 & Nr 7 & Nr 8 & Nr 9 & Nr 10 \\
\hline $\mathrm{Si}$ & 26 & 26 & 26 & 28 & 35 & 40 & 35 & 26 & 20 & 15 \\
$\mathrm{Al}$ & 10 & 10 & 10 & 10 & 6 & 3 & 4 & 10 & 6 & 3 \\
$\mathrm{Mg}$ & 2 & 2 & 2,5 & 2 & 1 & 0,5 & 1,5 & 2 & 1 & 0,4 \\
$\mathrm{Ca}$ & 1 & $\mathrm{I}$ & 1 & 0,5 & 2 & 1 & 1,5 & 1 & 0,2 & 0,2 \\
$\mathrm{Fe}$ & 1,5 & 1,8 & 2,5 & 2,5 & 2,5 & 1 & 1 & 1,8 & 2,5 & 1 \\
$\mathrm{Mn}$ & 0,04 & 0,04 & 0,04 & 0,004 & 0,05 & 0,02 & 0,08 & 0,04 & 0,03 & 1 \\
$\mathrm{Na}$ & 0,4 & 0,4 & 0,6 & 0,8 & 0,6 & 0,6 & 0,7 & 0,4 & 0,6 & - \\
$\mathrm{Ni}$ & 0.006 & 0,006 & 0,006 & 0,015 & 0,004 & 0,004 & 0,01 & 0,18 & 0,01 & 0,0004 \\
$\mathrm{Co}$ & 0,003 & 0,003 & 0,003 & 0,002 & 0,002 & 0,003 & 0,002 & 0,00 & 0,003 & 0,0006 \\
$\mathrm{Ti}$ & 0,4 & 0,6 & 0,5 & 0,5 & 0,04 & 0,3 & 0,5 & 0,4 & 0,2 & 0,5 \\
$\mathrm{~V}$ & 0,01 & 0,01 & 0,01 & 0,02 & 0,01 & 0,01 & 0,015 & 0,021 & 0,013 & 0,001 \\
$\mathrm{Cr}$ & 0,01 & 0,008 & 0,008 & 0,01 & 0,006 & 0,006 & 0,006 & 0,4 & 0,008 & 0,002 \\
$\mathrm{Cu}$ & 0,07 & 0,09 & 0,2 & 0,2 & 0,04 & 0,03 & 0,2 & 1 & 0,8 & 0,25 \\
$\mathrm{~Pb}$ & 0,002 & 0,003 & 0,003 & 0,003 & 0,001 & 0,003 & 0,001 & 0,09 & 0,009 & 0,002 \\
$\mathrm{Zn}$ & 0,02 & 0,02 & 0,02 & 0,01 & 0,02 & 0,03 & 0,01 & - & - & 0,01 \\
$\mathrm{Ga}$ & 0,003 & 0,003 & 0,002 & 0,005 & 0,002 & 0,002 & 0,001 & 0,003 & 0,003 & 0,0001 \\
$\mathrm{Be}$ & $\mathrm{s} l \mathrm{ad}$ & 0,001 & 0,25 & 0,001 & 0,001 & 0,001 & ślad & 0,001 & 0,0003 & 0,0001 \\
$\mathrm{Ba}$ & 0,2 & 0,25 & 0,008 & 0,1 & 0,25 & 0,15 & 0,3 & 0,04 & - & 0,1 \\
$\mathrm{~B}$ & 0,008 & 0,008 & 0,6 & 0,008 & 0,008 & 0,008 & 0,008 & 0,008 & 0,004 & - \\
$\mathrm{Sn}$ & 0,0003 & 0,0003 & 0,0003 & 0,0003 & 0,0003 & 0,0003 & 0,0003 & 0,0001 & 0,0001 & - \\
$\mathrm{Mo}$ & 0,001 & 0,0006 & 0,0012 & 0,0006 & 0,0007 & 0,0006 & 0,0007 & 0,0005 & 0,0008 & 0,0003 \\
$\mathrm{Nb}$ & - & - & - & - & - & - & - & - & 0,0006 & 0,0004 \\
$\mathrm{Bi}$ & - & - & - & - & - & - & - & - & - & 0,0001 \\
$\mathrm{Zr}$ & 0,06 & 0,06 & 0,08 & 0,03 & 0,04 & 0,1 & 0,1 & 0,04 & 0,5 & 0,004 \\
$\mathrm{OSb}$ & - & - & - & - & - & - & - & - & 0,0001 & - \\
\hline
\end{tabular}

Odcinki: Usteczko (Nr 1-3 - iłowce; Nr 4-5 - mułowce; Nr 6-7 - piaskowce); Iwane-Zolote (Nr 8 - iłowiec; Nr 9 mułowiec); Bilcze-lwane ( $\mathrm{Nr} 10$ - piaskowiec).

zek tego ostatniego z substancją organiczna, której zawartość osiąga czasami 10 $15 \%$. Należy zwrócić uwagę na często spotykany wzrost zawartości Ba i P, co wiąże się bezpośrednio $z$ obecnością resztek ryb pancernych w skałach.

$\mathrm{Z}$ wyjątkiem skał rudonośnych, zawierających malachit $\mathrm{i}$ azuryt, ilość $\mathrm{Cu}$ z reguły nie przewyższa $1 \%$. Jednak najwięcej $\mathrm{Cu}$ spotyka się w iłowcach, iłowcach zawierających substancję organiczną oraz mułowcach. Zawartość $\mathrm{Pb}$ nie przewyższa setnych części procenta, a $\mathrm{Ni}$ i Ba w rzadkich przypadkach sięga $0,1 \%$.

Korelacja geochemiczna kompleksów warstwowych licznych wychodni rud zawierających $\mathrm{Cu}$ świadczy o znacznym zróżnicowaniu współwystępowania pier- 
wiastków chemicznych. Określa się to przez stopień zwietrzenia i hydrodynamiczne warunki osadzania się oraz typy skał. Na przykład maksima zawartości Ni, V, Co, $\mathrm{Li}, \mathrm{Sn}, \mathrm{Pb}, \mathrm{Bo}, \mathrm{Cr}$ występują w skałach ilastych; Ti i $\mathrm{Zn}$ występują w piaskowcach; $\mathrm{Ba}, \mathrm{Cu}, \mathrm{Sr}$ tworzą grupę pierwiastków spotykanych w piaskowcach i w mulowcach. W skałach miedzionośnych (piaskowce oraz iłowce) miejscami występuje więcej $\mathrm{Cu}, \mathrm{Pb}, \mathrm{Y}, \mathrm{Mo}$, co spowodowane jest geochemią procesów sedymentacji i osobliwościa wyjściowego materiału macierzystego ${ }^{8}$.

Geochemiczna korelacja pierwiastków chemicznych może różnić się również w granicach wychodni. Dla usteckiego kompleksu warstwowego charakterystyczny jest rząd korelacyjny $\mathrm{Cu}, \mathrm{Mo}, \mathrm{V}$. W wychodni Chmielowa wydzielić można grupy: $\mathrm{Ti}, \mathrm{Zn}, \mathrm{Cr}$ i $\mathrm{Cu}, \mathrm{Mo}, \mathrm{Pb}$. W ostatnim przypadku trwały związek Cu i Mo wskazuje na oddziaływanie substancji organicznej i procesów hipergenicznych. Na równi z maksymalną zawartością Cu i Mo wzrasta obecność P i Y, co w skałach piaszczystych wiąże się z obecnością kości ryb.

Drugi przykład (miejscowość Usteczko) świadczy o istnieniu innych rzędów korelacyjnych. Cu znajduje się tu w rzędzie reprezentowanym przez $\mathrm{V}, \mathrm{B}, \mathrm{Ni}, \mathrm{Ti}, \mathrm{Cr}$, $\mathrm{Se}, \mathrm{Co}, \mathrm{Su}, \mathrm{Li}$. Drugą grupę stanowią $\mathrm{Y}, \mathrm{Yb}, \mathrm{Zn}, \mathrm{Mo}$; a trzecią- $\mathrm{Mn}, \mathrm{Sr}, \mathrm{Pb} . \mathrm{Na}$ innych wychodniach można dostrzec rzędy pokrewne lub odmienne temu zestawowi pierwiastków chemicznych.

Wyżej wymienione właściwości korelacji geochemicznej skał o zróżnicowanym składzie litologicznym w obrębie odsłonięć rud Cu świadczą o złożoności ich wykorzystania do interpretacji składu chemicznego metalowych zabytków archeologicznych. Widocznie w takim przypadku główną rolę powinna odgrywać ilościowa zawartość pierwiastków chemicznych i ich lokalizacja w rudzie oraz w otrzymanym z niej metalu.

$\mathrm{Na}$ podstawie analizy składu chemicznego skał miedzionośnych Naddniestrza można przypuszczać, że otrzymany $\mathrm{z}$ nich metal powinien być reprezentowany przez $\mathrm{Cu}$, a w rzadkich przypadkach przez brąz, stop $\mathrm{Cu}-\mathrm{Pb}$. Całkowity brak $\mathrm{Bi}$, tysięczne części procenta Sn oraz prawie całkowity brak As w skałach to główne kryterium geochemiczne do ustalenia związku genetycznego metalu pradziejowego ze złożami miedzionośnymi Naddniestrza.

II. Zapadlisko Przykarpackie, należące do systemu wypiętrzeń alpejskich Eurazji, ze względu na położenie i charakter wypełnienia kompleksu formacji stanowi zewnętrzną depresję przedgórską. Struktura ta otacza masyw Karpat od wschodu, północy i południa. Za współczesną granicę luku Karpat uważa się linię nasunięcia karpackiego. Zewnętrzna granica zapadliska, z krańcami południowo-zachodnimi Platformy Wschodnioeuropejskiej, przebiega wzdłuż przerywanej linii kulisowo rozmieszczonych uskoków i fleksur, które prawdopodobnie odtwarzaja pęknięcie głębinowe. Szerokość łuku Karpat na terenie Ukrainy wynosi do 40 km w częściach

\footnotetext{
${ }^{8}$ Nikiphorova i inni 1972, s. 262.
} 
północno-zachodniej i środkowej, a w krańcowej części południowo-wschodniej $-4 \mathrm{~km}$.

Do niedawna przyjmowano dwuczęściowy schemat podziału łuku karpackiego, według którego wyodrębnić można strefy: wewnętrzną i zewnętrzną. Pierwsza z nich stanowi część fałdowego obszaru Karpat, pochodzącą z neogeńskiego nagromadzenia molasowego. Razem $\mathrm{z}$ fundamentem fliszowym zostały one spiętrzone w fałdy, a także złożone nasuniętymi płaszczowinami i poprzecznymi uskokami oraz zgrupowane w pokrywy o mniejszych rozmiarach. Druga, wygięta krawędź platformy $z$ kompleksem molasowym została słabo dotknięta procesami fałdowania.

W odróżnieniu od strefy zewnętrznej - autochtonicznej, strefa wewnętrzna jest allochtoniczna, ze zwykłą dla Karpat Wschodnich wergencją północno-wschodnią.

W Zapadlisku Przykarpackim wyróżnia się dwie formacje": dolnomolasową haloidalną (solonośno-haloidalno-terygeniczna) i górnomolasową (haloidalno-terygeniczna). Pierwsza $z$ nich formowała się na wczesnoorogenicznym, druga - na późnoorogenicznym etapie rozwoju karpackiego systemu geosynklinalnego.

Stosownie do składu materialnego, z uwzględnieniem warunków paleograficznych, w formacji dolnomolasowej występują 4 subformacje: morska haloidalnoterygeniczna o szarej barwie, gipsonośna (warstwy polanickie), morska terygeniczno-solonośna (kompleks worotyszczeński), morska miedzionośna czerwono-terygeniczna (warstwy stebnickie) oraz morska solonośno-terygeniczna (warstwy balickie). Formacja górnomolasowa zawiera cztery subformacje: morską piaszczysto-ilasto-marglistą (warstwy bohorodczańskie), solonośną (warstwy tyraskie), morską szarą piaszczysto-ilastą (warstwy kosowskie) i kontynentalno-morską szarą piaszczysto-ilastą (warstwy daszawskie). Wiek miedzionośnej formacji czerwono-terygenicznej (warstwy stebnickie) początkowo uważany był za burdygalski (egenburski ${ }^{10}$. Zgodnie $z$ nowymi danymi stratygraficznymi ${ }^{11}$ wiek warstw stebnickich zaliczono do wieku ottanganskiego ${ }^{12}$.

$\mathrm{Na}$ ogół warstwy stebnickie reprezentowane są przez skały terygeniczne. Przeważają tu skały ilaste i mieszane mułowcowo-piaszczysto-ilaste. W podrzędnych ilościach stwierdzono tu piaskowce, znacznie rzadziej zlepieńce i grawelity. Skały te są źle wysortowane, o szarym i czerwonym zabarwieniu. Pigmentem barwiącym są tu związki Fe, które razem z substancją ilastą pelnią rolę spoiwa skał klastycznych. Miąższość warstw stebnickich wynosi $700-800 \mathrm{~m}$, a w części północno-zachodniej sięga $2500 \mathrm{~m}$.

$\mathrm{Na}$ terenie Zapadliska Przykarpackiego, w południowo-wschodniej i centralnej jego części, mineralizacja Cu badana była na obszarach: Nadwórniańskim, Łojew-

${ }^{9}$ Khrushchov, Kompanec 1988, s. 196.

"Burov i inni 1971, s. 42-54; Krasheninnikov 1971, s. 150.

"Andreyeva-Grigorovich, Stupnickiy 1976, s. 139; Venglinskiy, Goreckiy 1979, s. 174; Stratigraphiya USSR, s. 270.

${ }^{12}$ Steininger, Rogl 1982, s. 66-67. 


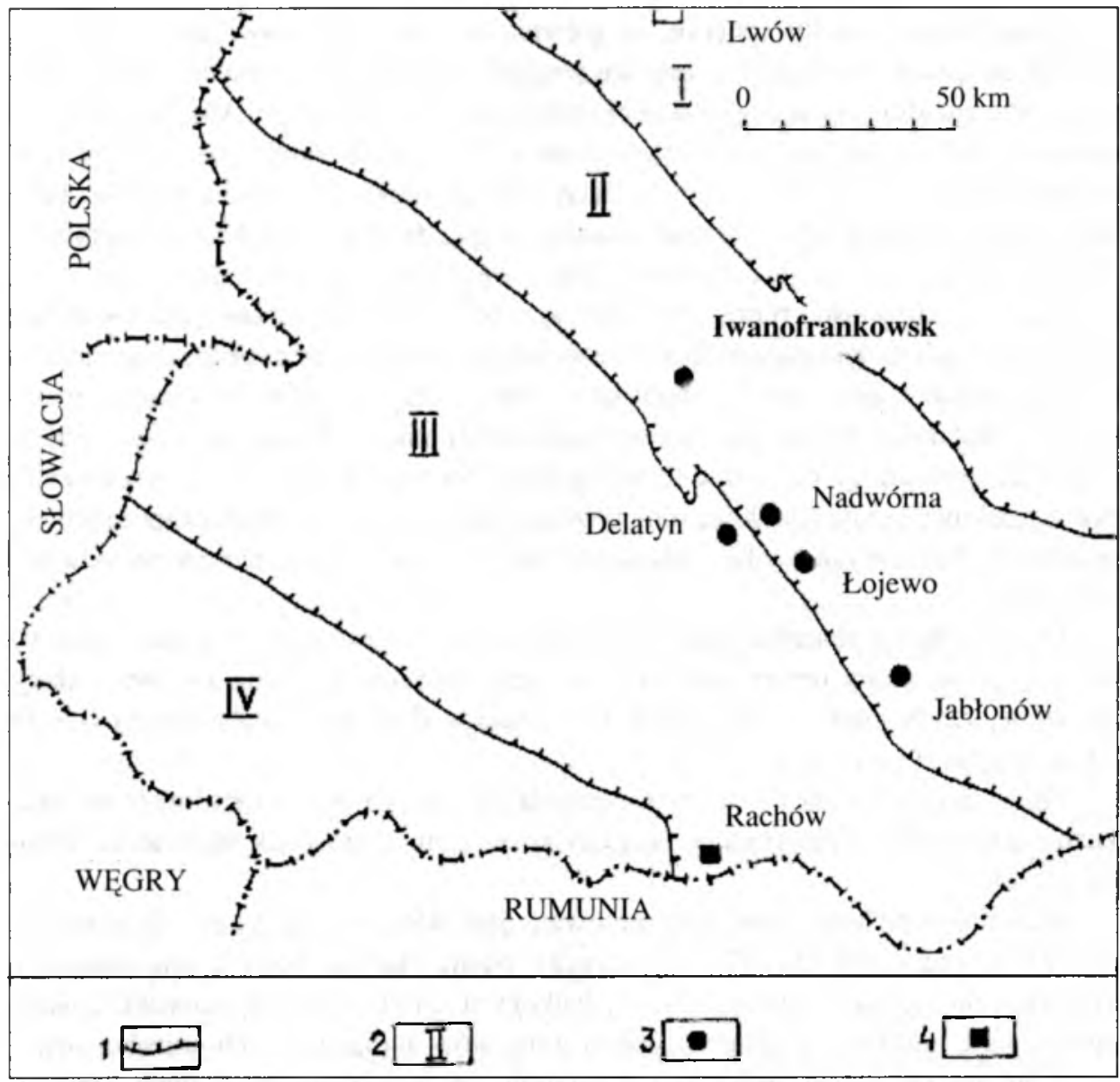

Ryc. 2. Schematyczna mapa rozmieszczenia wychodni rud miedzi w kompleksie stebnickim Przykarpacia i kompleksie diloweckim Rachowskiego Masywu Krystalicznego (Karpaty). Rys. V. Manichev

I. Obramowanie platformowe Karpat; II. Zapadlisko Przykarpackie; III. Karpaty fliszowe; IV. Łuk Karpat. 1 - granice stref strukturalno-tektonicznych; 2 - strefy tektoniczne; 3 - wychodnia skał miedzionośnych kompleksu stebnickiego; 4 - wychodnia rud pirytów miedzionośnych kompleksu diłoweckiego.

Specjalizacja geochemiczna wystapień nud miedzi wg danych „Zachód geologii”: Kałusz - Cu(Ag, Pb, Zn, Mn, Ba), Nadwórna - $\mathrm{Cu}(\mathrm{Ag}, \mathrm{Pb}, \mathrm{Zn}, \mathrm{Mn})$, Delatyn - Cu(Ag, Mn, Ba, Sr), Jabłonów - $\mathrm{Cu}(\mathrm{Ag})$, Łojewo - Cu( Ag, Pb)

Fig. 2. Diagrammatic map of copper ore manifestations location in Predcarpathie Stebnyk and Delovetsky complex of Rakhov crystalline massif (Carpatians). By V. Manichev

skim, Latowieckim, Jabłonowskim, Molodiatynskim, Delatynskim, Kałuskim (ryc. 2). Rudy $\mathrm{Cu}$ na tych obszarach pojawiają się w dwóch poziomach stratygraficznych w przecięciu warstw stebnickich (fot. 3a). Część wychodni znajduje się w górnej części dolnej strefy warstw, w której wydziela się jeden horyzont miedzionośny. Większość odsłonięć rud $\mathrm{Cu}$ występuje w środkowej warstwie produktywnej, zawierającej na różnych obszarach po 3-4 horyzonty miedzionośne. 
Zmineralizowaną $\mathrm{Cu}$ spotyka się głównie w szarych piaskowcach deltowych, skałach mieszanych i ilach z domieszką węglistej substancji organicznej. Skały miedzionośne znajdują się w części dolnej profilu osadów deltowych. Mineralizację $\mathrm{Cu}$ dostrzec można częściowo w szarych skałach mieszanych, rzadziej - w iłach facji przybrzeżno-morskiej, przeważnie w iłach szarych, niekiedy w skałach mieszanych facji płytkomorskiej. Dla skał miedzionośnych przybrzeżno-morskich i płytkomorskich charakterystyczna jest obecność śladów węglistej substancji organicznej.

Facje miedzionośne reprezentowane są przez określony zestaw podstawowych typów skal, ich ilościową współzależność, formę występowania, miąższość i jednolitość na płaszczyźnie, skład granulometryczny i mineralny oraz właściwości strukturalno-teksturalne. Facje deltowe, jako najbardziej miedzionośne, zawierają do $10 \%$ objętości subformacji czerwono-terygenicznej. Reprezentowane są one przeważnie przez piaskowce szare (do $90 \%$ ) o miąższości od 0,5 do 2-3 m. Małą grupę stanowią warstewki skał szarych o nikłej miąższości (od 0,01 do $0,1 \mathrm{~m}$ ) i mieszanym składzie oraz iłów.

Osady deltowe charakteryzują się rytmicznością. Sekwencje mają budowę dwudzielna: część dolna reprezentowana jest przez piaskowce, górna zaś przez skały mieszane, rzadko przez muły. Miąższość osadów deltowych waha się od 0,5 do $25 \mathrm{~m}$, średnio wynosząc od 3-5 m.

Skład mineralny iłów o różnym pochodzeniu, w tym miedzionośnych, nie wykazuje istotnych zmian; zmianie ulega tylko wzajemny stosunek minerałów skałotwórczych.

Materiał okruchowy iłów reprezentowany jest głównie przez kwarc allogeniczny (do 95\%), muskowit (5-10\%), pojedyncze ziarna skaleni, biotytu oraz minerały akcesoryczne: granat, cyrkon, ilmenit, leukoksen, rutyl, turmalin, staurolit, anataz, apatyt, sfen, amfibole, magnetyt. Wśród minerałów autogenicznych szeroko rozpowszechnione są: kalcyt pelityczny i dolomit. W miedzionośnych iłach szarych, oprócz wymienionych wyżej minerałów pojawia się chalkozyn, występujący z reguły $w$ wychodniach zawierających zwęglone resztki roślinne $w$ formie drobnych wtrąceń wśród podstawowej masy skalnej. Oprócz tego ujawniono pojedyncze ziarna chalkopirytu, lelingitu, jalpaitu i smaltynu ${ }^{13}$. Wśród minerałów wtórnych najczęściej zaobserwować można malachit, rzadziej - dygenit, kupryt, kowelin i miedź samorodną, rozwijające się po chalkozynie w strefie utleniania.

Masa podstawowa iłów reprezentowana jest przez minerały ilaste: hydromiki, montmorillonit, rzadziej kaolinit oraz chloryt. Jako domieszka mineralna występuje kwarc.

Skały o skladzie mieszanym trudno odróżnić w warunkach terenowych od drobnoziarnistych piaskowców ilastych. Na podstawie składu granulometrycznego można stwierdzić, że skały te reprezentują fację piaskowcowo-mulasto-ilastą.

\footnotetext{
${ }^{13}$ Khrushchov i inni 1977, s. 48.
} 
Skład mineralny frakcji mułowcowej i piaszczystej skał mieszanych reprezentowany jest, podobnie jak w iłach, przeważnie przez kwarc (90-95\%), muskowit i pojedyncze ziarna skaleni, biotytu i minerałów aksesorycznych, wśród których występują pojedyncze ziarna piroksenów. W odmianach szarych występują fragmenty zwęglonych substancji organicznych.

Skład spoiwa skał mieszanych jest zbliżony do składu podstawowej masy iłów, ale z nieco innym stosunkiem minerałów. Charakteryzuje się on wyższą zawartością węglanów w stosunku do iłów, która sięga średnio 20\%. Forma i rozmiar cząstek ilastych oraz ich zestaw w skałach mieszanych są identycznie jak w iłach, a współwystępowanie minerałów miedzionośnych skał szarych o składzie mieszanym w iłach miedzionośnych. Biorąc pod uwagę współzależność części okruchowej i spoiwa w opisanych skałach można wydzielić dwa jego typy: bazalny i porowy.

Skład granulometryczny i mineralny piaskowców zróżnicowanych typów facjalnych, w tym deltowych piaskowców miedzionośnych, nie wykazuje dużych różnic. Należy pod tym względem wyróżnić piaskowce mulaste i ilasto-mułowcowe. Odmiana średnio- i drobnoziarnista jest spotykana najczęściej. W części okruchowej piaskowców ujawniono kwarc (85-90\%), skalenie (do 10\%) i muskowit (do 5\%). Regularnie spotyka się oddzielne ziarna biotytu i minerałów akcesorycznych.

Wśród minerałów akcesorycznych obecne są najczęściej: granat, ilmenit, cyrkon, rutyl, turmalin, staurolit. We frakcjach ciężkich, oprócz wymienionych już wyżej, zauważyć można pojedyncze ślady magnetytu, epidotu, amfiboli i piroksenów.

Skład spoiwa piaskowców (do $50 \%$ objętości skały) nie różni się zasadniczo od składu masy podstawowej iłów i spoiwa skał mieszanych. Notuje się tu spoiwo węglanowe, ilasto-węglanowe, węglanowo-ilaste typu bazalnego i błonowo-porowego. Ważną rolę odgrywają tu często tlenki i wodorotlenki Fe. Wśród węglanów przeważa kalcyt pelitowy. Tlenki i wodorotlenki Fe (do 5\%) rozkładają się w skale równomiernie, tworząc miejscami skały laminowane.

Piaskowce odznaczają się podwyższoną zawartością węglistego detrytusu roślinnego w całej masie skalnej.

Podstawowym minerałem rudnym piaskowców miedzionośnych oraz innych skał - iłów i skał o mieszanym składzie - jest chalkozyn rozwinięty w dwóch generacjach. Chalkozyn pierwszej generacji występuje w postaci licznych wtrąceń w spoiwie, czasem zastępując go całkowicie, lub w postaci odrębnych wrostków, rzadziej soczewek, z reguły na odcinkach zawierających zwęglone resztki roślinności. Chalkozyn drugiej generacji rozwija się w postaci owalnych tworów (,globul”) wśród resztek organicznych lub koncentruje się wzdłuż pęknięć.

Wystapienia chalkozynu są ksenomorficzne i skupiają się w cemencie piaskowców tworząc spoiwo typu porowego, rzadziej zastępując prawie zupełnie część węglanową spoiwem bazalnym. Wyjątkowo rzadko spotyka się odrębne ziarna chalkozynu w kształcie zbliżonym do rombu. 
Skład chemiczny chalkozynu oznaczony metodą mikrorentgenowsko-spektralną, przedstawiono w tabeli 3 .

Tabela 3

Wyniki analizy chemicznej chalkozymu (\%)

Table 3

The chalcosine chemical analysis results (\%)

\begin{tabular}{|c|c|c|c|c|}
\hline \multicolumn{3}{|c|}{ Sklad (\% wag.) } & \multirow{2}{*}{ Suma (\%) } & \multirow{2}{*}{$\begin{array}{c}\text { Formacje } \\
\text { mineralogiczne }\end{array}$} \\
\hline $\mathrm{Cu}$ & $\mathrm{Fe}$ & $\mathrm{S}$ & & chalkozyn I \\
78,1 & 0,8 & 19,8 & 98,7 & chalkozyn I \\
76,9 & 2,0 & 19,8 & 98,7 & dygenit \\
78,4 & 0,4 & 21,5 & 100,3 & chalkozyn I \\
\hline
\end{tabular}

Dygenit dosyć często rozwija się na ziarnach chalkozynu, tworząc struktury obwódek. Czasem wyodrębnia się on w postaci żyłek chalkozynu. Miąższość obwódek i żyłek nie przewyższa $0,5-0,8 \mathrm{~mm}$. Na granicy dygenitu i zastępującego go chalkozynu miejscami zauważa się włókniste i punktowe wytrącenia miedzi rodzimej. Niekiedy chalkozyn zastępowany jest przez miedź rodzima, która współwystępuje dosyć często z kuprytem, koncentrując się przeważnie w postaci drobnych, wrośniętych ziaren. Tylko w odosobnionych przypadkach wytwarza samodzielne skupienia. Kupryt w postaci obwódek i żyłek, a także oddzielnie wyodrębnionych ziaren, występuje w badanych próbkach w znacznie mniejszych ilościach (kupryt całkowicie zastępuje tu chalkozyn).

Pojedyncze ziarna chalkopirytu obecne sa w piaskowcach. Ziarna te są zwykle ksenomorficzne i zaokraglone, dopasowane do spoiwa skał. Rozmiar ziaren nie przewyższa $0,01 \mathrm{~mm}$. W pojedynczych przypadkach w szlifach polerowanych notuje się kowelin, lelingit, alpait i smaltyn. W miejscach wychodni piaskowców miedzionośnych i iłów występuje malachit.

Piaskowce miedzionośne (tab. 4) są stosunkowo bogate w krzemionkę (średnia zawartość 62\%) i odpowiednio zubożone o $\mathrm{Al}_{2} \mathrm{O}_{3}(7,9 \%)$. Zawartość $\mathrm{TiO}_{2}$ w tych skałach wynosi średnio $0,57 \%$. Podstawowymi nosicielami Ti są minerały akcesoryczne, w których średnia zawartość $\mathrm{Na}_{2} \mathrm{O}$ wynosi $1,99 \%$, przewyższając nieznacznie $\mathrm{K}_{2} \mathrm{O}$ (średnio $1,48 \%$ ). Charakterystyczne są dosyć wysokie zawartości $\mathrm{CaO}$ $(9,07 \%)$ i $\mathrm{MgO}(2,76 \%)$. Średnia zawartość $\mathrm{MnO}$ wynosi $0,08 \%$, a zawartość $\mathrm{Fe}_{2} \mathrm{O}_{3}$ $(1,3 \%)$ jest wyższa w stosunku do $\mathrm{FeO}(0,66 \%)$, co świadczy o słabo redukcyjnych warunkach osadzania się piaskowców. Zawartość $\mathrm{CuO}$ waha się od 0,44 do $2 \%$ i wynosi średnio $1,09 \%$. 
Tabela 4

Wyniki analizy chemicznej skał miedzionośnych Przykarpacia (\%)

Table 4

The Predcarpathie cuprous rocks chemical analysis results (\%)

\begin{tabular}{|c|c|c|c|c|c|}
\hline \multirow[b]{2}{*}{$\begin{array}{l}\text { Związek } \\
\text { chemiczny }\end{array}$} & \multicolumn{5}{|c|}{ Nr wzorca mineralnego, facja, miejsce pobrania próby } \\
\hline & $\begin{array}{c}\text { próba } 193 \\
\text { iły szare, } \\
\text { przybrzeżno- } \\
\text { morskie, obszar } \\
\text { M-120, Łan- } \\
\text { czyn, rzeka Prut }\end{array}$ & $\begin{array}{c}\text { próba } 244 \\
\text { iły szare, mor- } \\
\text { skie, obszar } \\
\text { M-45, potok } \\
\text { Rotunziwa }\end{array}$ & $\begin{array}{c}\text { próba } 27 \\
\text { piaskowiec } \\
\text { szary, przy- } \\
\text { brzeżno-morski, } \\
\text { obszar M-7, } \\
\text { Łojewo, potok } \\
\text { Latowiec }\end{array}$ & $\begin{array}{c}\text { próba } 39 \\
\text { piaskowiec } \\
\text { szary, przy- } \\
\text { brzeżno-morski, } \\
\text { obszar M-19, } \\
\text { Łojewo, potok } \\
\text { Latowiec }\end{array}$ & $\begin{array}{c}\text { próba } 75 \\
\text { piaskowiec } \\
\text { szary, deltowy, } \\
\text { obszar M-31, } \\
\text { prawy brzeg } \\
\text { rzeki Łuczka }\end{array}$ \\
\hline $\mathrm{SiO}_{2}$ & 49,00 & 50,18 & 61,00 & 64,22 & 62,21 \\
\hline $\mathrm{TiO}_{2}$ & 0,67 & 0,75 & 0,47 & 0,588 & 0,57 \\
\hline $\mathrm{Al}_{2} \mathrm{O}_{3}$ & 13,38 & 15,23 & 5,75 & 6,50 & 7,91 \\
\hline $\mathrm{Fe}_{2} \mathrm{O}_{3}$ & 1,70 & 2,16 & 0,12 & 1,12 & 0,66 \\
\hline $\mathrm{CaO}$ & 13,21 & 9,87 & 10,44 & 9,97 & 9,07 \\
\hline $\mathrm{MgO}$ & 2,53 & 3,42 & 1,85 & 2,04 & 2,76 \\
\hline $\mathrm{K}_{2} \mathrm{O}$ & 2,26 & 2,30 & 1,05 & 1,14 & 1,48 \\
\hline $\mathrm{Na}_{2} \mathrm{O}$ & 0,45 & 0,70 & 0,84 & 0,95 & 1,99 \\
\hline $\mathrm{FeO}$ & 1,62 & 1,75 & 1,43 & 1,29 & 1,30 \\
\hline $\mathrm{MnO}$ & 0,11 & 0,14 & 0,18 & 0,12 & 0,09 \\
\hline $\begin{array}{l}\mathrm{P}_{2} \mathrm{O}_{5} \\
\text { strata przy }\end{array}$ & 0,11 & 0,11 & 0,10 & 0,12 & 0,08 \\
\hline nagrzewaniu & 14,54 & 12,71 & 3,35 & 2,70 & 3,57 \\
\hline $\mathrm{SO}_{3}$ & 0,079 & 0,051 & 5,58 & & \\
\hline$\Sigma$ & 99,83 & 98,78 & 99,82 & 99,76 & 100,3 \\
\hline$S_{\text {ogólny }}$ & 0,11 & 0,027 & ślad & ślad & 0,14 \\
\hline$S$ & 0,075 & 0,007 & & & \\
\hline $\mathrm{C}_{\text {ogólny }}$ & 2,88 & 2,40 & 0,14 & 0,18 & 0,43 \\
\hline $\mathrm{CO}_{2}$ weglowy & 2,58 & 2,16 & 5,10 & 8,46 & 6,46 \\
\hline $\mathrm{C}_{\text {organiczny }}$ & 0,30 & 0,24 & & & \\
\hline $\mathrm{SiO}_{2}$ & 0,65 & 1,27 & & & \\
\hline $\mathrm{CuO}$ & 0,168 & 0,413 & 0,18 & 0,11 & 1,09 \\
\hline $\mathrm{H}_{2} \mathrm{O}$ & & & 2,24 & 0,26 & 0,60 \\
\hline
\end{tabular}

W skałach miedzionośnych o składzie mieszanym zauważa się niższe zawartości krzemionki ( $\sim 53 \%)$ i odpowiednio podwyższone $\mathrm{Al}_{2} \mathrm{O}_{3}(\sim 14 \%)$. Ilość $\mathrm{TiO}_{2}$ wynosi średnio $0,8 \%$, przewyższając nieco jego zawartość w piaskowcach miedzionośnych. W skałach tych ilość $\mathrm{K}_{2} \mathrm{O}(2,2 \%)$ przewyższa $\mathrm{Na}_{2} \mathrm{O}(0,8 \%)$. Zawartość $\mathrm{CaO}$ $(-9 \%)$ i $\mathrm{MgO}(\sim 3 \%)$ jest stosunkowo wysoka. Spostrzec można zbliżone ilości FeO i $\mathrm{Fe}_{2} \mathrm{O}_{3}$ (średnio $1,9 \%$ ). Zawartość $\mathrm{CuO}$ waha się od 0,01 do $0,34 \%$, natomiast zawartość $\mathrm{MnO}$ jest stosunkowo niska i wynosi do $0,11 \%$. 
Wyniki analizy spektralnej skał miedzionośnych Przykarpacia (\%)

Table 5

Predcarpathie cuprous rocks spectrum analysis results (\%)

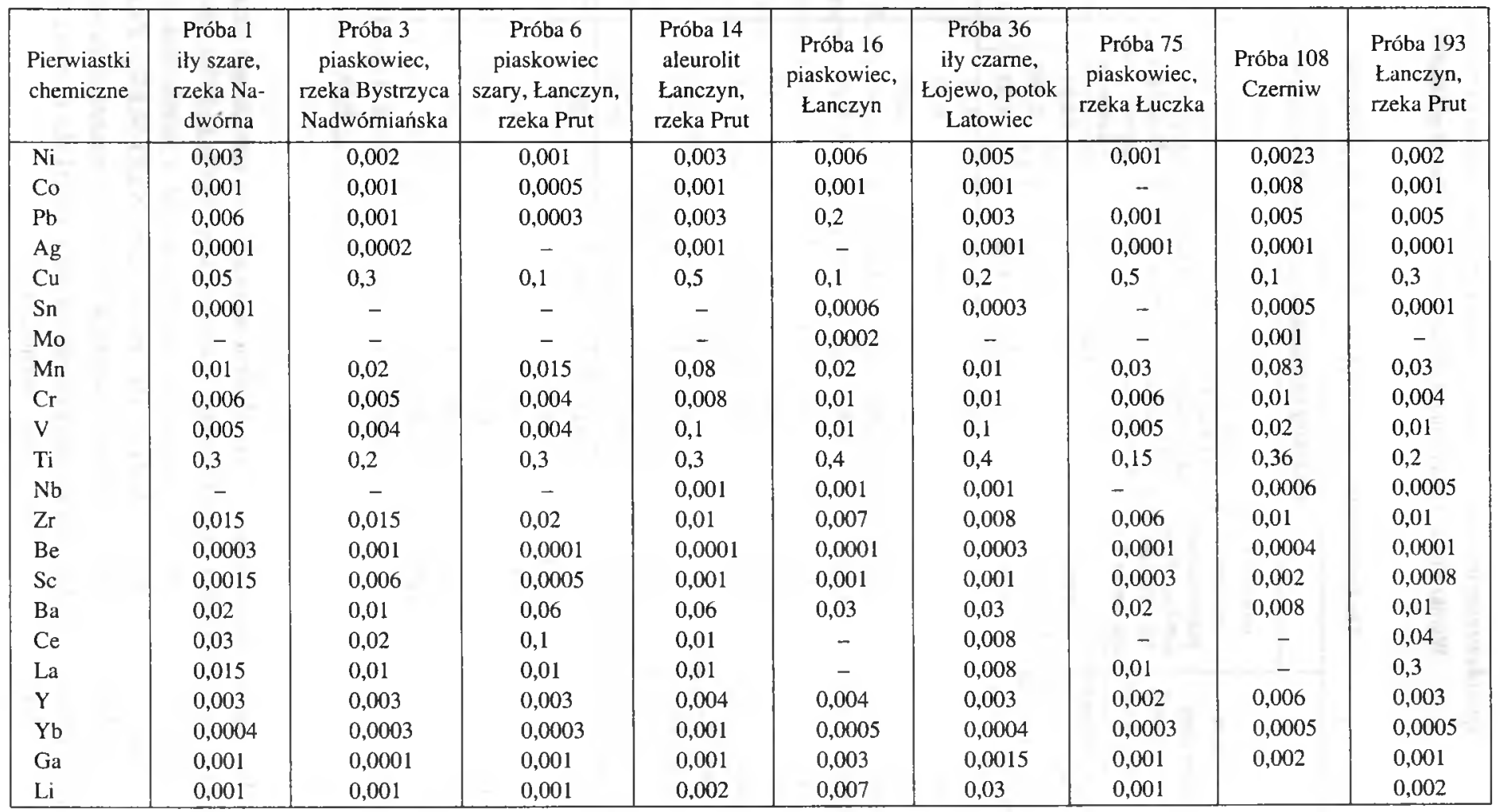


Wyniki analizy spektralnej skał miedzionośnych Przykarpacia (\%)

Table 6

Predcarpathie cuprous rocks spectrum analysis results (\%)

\begin{tabular}{|c|c|c|c|c|c|c|c|c|}
\hline $\begin{array}{l}\text { Pierwiastki } \\
\text { chemiczne }\end{array}$ & $\begin{array}{c}\text { Próba } 244 \\
\text { ily szare, potok } \\
\text { Rotunziwa }\end{array}$ & $\begin{array}{c}\text { Próba } 302 \\
\text { iły szare. Molo- } \\
\text { diatin, rzeka } \\
\text { Kobylica }\end{array}$ & $\begin{array}{c}\text { Próba } 304 \\
\text { piaskowiec, } \\
\text { Molodiatin, } \\
\text { rzeka Kobylica }\end{array}$ & $\begin{array}{c}\text { Próba } 318 \\
\text { iły szare, rzeka } \\
\text { Kobylica }\end{array}$ & $\begin{array}{c}\text { Próba } 323 \\
\text { piaskowiec } \\
\text { szary, Biale } \\
\text { Osławy, rzeka } \\
\text { Osława }\end{array}$ & $\begin{array}{c}\text { Próba } 359 \\
\text { piaskowiec. } \\
\text { Zarzecze, rzeka } \\
\text { Prut }\end{array}$ & $\begin{array}{c}\text { Próba } 360 \\
\text { piaskowiec, } \\
\text { rzeka Bystrzyca } \\
\text { Solotwińska }\end{array}$ & $\begin{array}{c}\text { Próba } 367 \\
\text { rzeka Bere- } \\
\text { znycze }\end{array}$ \\
\hline $\mathrm{Ni}$ & 0,003 & 0,01 & 0,001 & 0,02 & 0,003 & 0,009 & 0.002 & 0,001 \\
\hline $\mathrm{Co}$ & 0,001 & 0,002 & 0,001 & 0,002 & 0,001 & 0,005 & - & 0,0005 \\
\hline $\mathrm{Pb}$ & 0,003 & 0,01 & 0,001 & 0,01 & 0,006 & 0,008 & 0,006 & 0,002 \\
\hline $\mathrm{Ag}$ & - & 0,0005 & - & 0,001 & 0,0001 & 0,0001 & 0,006 & 0,0001 \\
\hline $\mathrm{Cu}$ & 0,3 & $>1,0$ & 0,2 & 0,1 & 0,1 & 1,0 & 0,3 & $0,1-2$ \\
\hline Sn & 0,0002 & 0,0003 & - & 0,001 & - & - & 0,0004 & - \\
\hline Mo & - & 0,0001 & - & 0,0002 & & 0,0008 & 0,0001 & - \\
\hline $\mathrm{Mn}$ & 0,1 & 0,03 & 0,06 & 0,04 & 0,04 & 0,06 & 0.003 & 0,02 \\
\hline $\mathrm{Cr}$ & 0,008 & 0,006 & 0,002 & 0,015 & 0,006 & 0,001 & 0,01 & - \\
\hline V & 0,01 & 0,02 & 0,003 & 0,02 & 0,01 & 0,008 & 0,015 & 0,004 \\
\hline $\mathrm{Ti}$ & 0,3 & 0,3 & 0,1 & 0,4 & 0,2 & 0,2 & 0,2 & 0,15 \\
\hline $\mathrm{Nb}$ & 0,0005 & 0,001 & 0,0004 & 0,002 & 0,0006 & 0,0006 & 0,001 & - \\
\hline 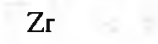 & 0,02 & 0,01 & 0,01 & 0,015 & 0,01 & - & 0,004 & 0,006 \\
\hline $\mathrm{Be}$ & 0,01 & 0,0001 & 0,0001 & 0,0002 & 0,0001 & 0,0001 & - & 0,0001 \\
\hline Sc & 0,04 & 0,0006 & 0,0003 & 0,003 & 0,002 & - & 0,002 & 0,0003 \\
\hline $\mathrm{Ba}$ & 0,01 & 0,04 & 0,01 & 0,02 & 0,01 & 0,004 & 0,01 & 0,04 \\
\hline $\mathrm{Ce}$ & 0,04 & - & 0,06 & - & 0,04 & - & - & - \\
\hline $\mathrm{La}$ & 0,04 & - & 0,02 & - & 0,02 & & 0,002 & - \\
\hline $\mathrm{Y}$ & 0,003 & 0,002 & 0,003 & 0,008 & 0,002 & 0,008 & 0,004 & 0,002 \\
\hline $\mathrm{Yb}$ & 0,0003 & 0,0005 & 0,0001 & 0,001 & 0,0002 & 0,0007 & 0,0003 & 0,0001 \\
\hline $\mathrm{Ga}$ & 0,001 & 0,001 & 0,001 & 0,001 & 0,001 & 0,003 & 0,001 & 0,006 \\
\hline $\mathrm{Li}$ & 0,003 & 0,005 & 0,001 & 0,006 & 0,002 & $\rightarrow$ & 0,001 & - \\
\hline
\end{tabular}


Tabela 7

Wyniki analizy spektralnej piaskowców miedzionośnych kompleksu stebnickiego Przykarpacia, odcinek Nadwórna (\%)

Table 7

Predcarpathie Stebnyk complex cuprous sandstone spectrum analysis (\%) results, Nadvornaya area

\begin{tabular}{|c|l|l|l|l|l|l|l|l|l|}
\hline $\begin{array}{c}\text { Pierwiastki } \\
\text { chemiczne }\end{array}$ & Nr 1 & Nr 2 & Nr 3 & Nr 4 & Nr 5 & Nr 6 & Nr 7 & Nr 8 & Nr 9 \\
\hline $\mathrm{Si}$ & $>5$ & $>5$ & 6 & 6 & 10 & 8 & 6 & 5 & 6 \\
$\mathrm{Al}$ & 1 & 0,6 & 6 & 3 & 3 & 1 & 1 & 5 & 5 \\
$\mathrm{Mg}$ & 0,3 & 0,3 & 0,6 & 0,5 & 0,3 & 0,2 & 0,2 & 0,6 & 1 \\
$\mathrm{Ca}$ & 2 & 0,2 & 5 & 0,2 & 0,1 & 0,2 & 0,2 & 0,5 & 0,3 \\
$\mathrm{Fe}$ & 4 & 0,4 & 0,5 & 0,6 & 1 & 0,5 & 0,5 & 2 & 2 \\
$\mathrm{Mn}$ & 0,5 & 0,01 & 0,02 & 0,01 & 0,02 & 0,01 & 0,01 & 0,02 & 0.01 \\
$\mathrm{Ni}$ & 0,0001 & 0,0001 & 0,0005 & 0,0004 & 0,0005 & 0,0002 & 0,0002 & 0,0002 & 0,001 \\
$\mathrm{Co}$ & - & - & 0,0001 & - & - & - & - & 0,0005 & 0,0004 \\
$\mathrm{Ti}$ & 0,05 & 0,02 & 0,06 & 0,06 & 0,1 & 0,06 & 0,6 & 0,15 & 0,10 \\
$\mathrm{~V}$ & 0,001 & 0,0005 & 0,002 & 0,001 & 0,001 & 0,0006 & 0,006 & 0,0005 & 0,004 \\
$\mathrm{Cr}$ & 0,0005 & 0,004 & 0,0010 & 0,001 & 0,0006 & 0,0005 & 0,0005 & 0,003 & 0,001 \\
$\mathrm{Mo}$ & 0,01 & 0,01 & - & 0,0006 & 0,001 & 0,01 & 0,01 & 0,002 & 0,004 \\
$\mathrm{Zr}$ & 0,004 & 0,03 & 0,006 & 0,010 & 0,004 & 0,004 & 0,004 & 0,006 & 0,005 \\
$\mathrm{Nb}$ & 0,0004 & 0,0002 & 0,0004 & 0,0005 & 0,0005 & 0,0003 & 0,0003 & 0,0006 & 0,0006 \\
$\mathrm{Cu}$ & $>2$ & $>2$ & 0,2 & 2 & 2,5 & 3 & 3 & 2 & 3 \\
$\mathrm{~Pb}$ & 0,045 & 0,045 & 0,003 & 0,015 & 0,015 & 0,03 & 0,03 & 0,0200 & 0,015 \\
$\mathrm{Ag}$ & 0,006 & 0,015 & 0,0001 & 0,005 & 0,003 & 0,01 & 0,01 & 0,005 & 0,004 \\
$\mathrm{Bi}$ & 0,0002 & 0,0001 & 0,0001 & 0,0001 & 0,0001 & 0,0001 & 0,0001 & 0,0001 & 0,0002 \\
$\mathrm{Zn}$ & 0,01 & - & 0,01 & 0,01 & 0,01 & - & - & 0,15 & 0,01 \\
$\mathrm{Sn}$ & 0,0001 & - & 0,003 & 0,0002 & - & 0,0001 & 0,0001 & 0,0003 & 0,0001 \\
$\mathrm{Ge}$ & 0,0010 & 0,0002 & - & 0,0001 & 0,0002 & 0,0003 & 0,0003 & 0,0003 & 0,0003 \\
$\mathrm{Ga}$ & 0,0001 & 0,0001 & 0,0004 & 0,0001 & 0,0001 & 0,0001 & 0,0001 & 0,0004 & 0,0002 \\
$\mathrm{Be}$ & 0,0001 & 0,0001 & 0,0001 & 0,0001 & 0,0001 & 0,0001 & 0,0001 & 0,0001 & 0,0001 \\
$\mathrm{Sc}$ & 0,0004 & 0,0002 & 0,0006 & 0,0005 & 0,0005 & 0,0003 & 0,0003 & 0,001 & 0,0005 \\
$\mathrm{Y}$ & 0,001 & 0,0006 & 0,002 & 0,001 & 0,0006 & 0,0006 & 0,0006 & 0,002 & 0,001 \\
$\mathrm{Yb}$ & 0,0001 & 0,0001 & 0,0002 & 0,0001 & 0,0001 & 0,0001 & 0,0001 & 0,0002 & 0,0001 \\
$\mathrm{P}$ & 0,2 & - & 0,2 & 0,1 & 0,1 & 0,1 & 0,1 & 0,2 & 0,2 \\
$\mathrm{Ba}$ & - & 0,05 & 0,01 & 0,01 & - & 0,01 & 0,01 & 0,01 & 0,01 \\
$\mathrm{Li}$ & 0,001 & 0,001 & 0,002 & 0,001 & 0,001 & 0,001 & 0,001 & 0,003 & 0,002 \\
\hline & & & & & & & & & \\
\hline
\end{tabular}

Iły miedzionośne, w odróżnieniu od innych skał rudnych, zawierają najniższą ilość krzemionki (do 50\%) i odpowiednio najwyższą $\mathrm{Al}_{2} \mathrm{O}_{3}$ (do 15\%). Zawartość $\mathrm{TiO}_{2}(0,7 \%)$ nie różni się w sposób istotny od zawartości tego składnika w innych skałach rudnych. Ilość $\mathrm{K}_{2} \mathrm{O}(2,3 \%)$ przewyższa $\mathrm{Na}_{2} \mathrm{O}(\sim 0,6 \%), \mathrm{CaO}(\sim 12 \%)$ i $\mathrm{MgO}$ $(\sim 3 \%)$, których zawartość jest dosyć wysoka, co jest charakterystyczne dla wszystkich skał miedzionośnych. Odnotowano również niską zawartość $\mathrm{MnO}(\sim 0,12 \%)$, 
zawartość $\mathrm{Fe}_{2} \mathrm{O}_{3}(-2 \%)$ nieznacznie przewyższa $\mathrm{FeO}(\sim 1,7)$, a $\mathrm{CuO}$ waha się od 0,168 do $0,413 \%$.

Według danych ilościowej analizy spektralnej dla każdego z wydzielonych typów skał miedzionośnych ustalono podstawową regularność rozpowszechnienia niektórych pierwiastków (tab. 5, 6 i 7).

Biorąc pod uwagę średnią zawartość pierwiastków śladowych w rudnych iłach płycizny morskiej maksymalnie koncentrują się tu: $\mathrm{Sn}, \mathrm{Cr}, \mathrm{Zr}, \mathrm{Be}, \mathrm{Sc}, \mathrm{La}, \mathrm{Y}, \mathrm{Ga}$; w rudnych iłach mielizny przybrzeżnej - $\mathrm{Co}, \mathrm{Pb}, \mathrm{Ce}$; a w rudnych piaskowcach deltowych - Ag i Nb.

Zgodnie ze schematem zwiazków korelacyjnych i korelacji wielokrotnej, w wyróżnionych typach genetycznych skał, zarysowuje się geochemiczne współwystępowanie pierwiastków śladowych. W rudnych piaskowcach deltowych odnotowano ścisłe związki korelacyjne (r $>0,75)$ Ba z Ti, Yb z Cr, V z Pb, La z Ce i Mn z Mo. $\mathrm{W}$ formule korelacji wielokrotnej rudnych piaskowców deltowych

$$
\left(\left((\mathrm{Mo}, \mathrm{Zr}, \mathrm{Mn}, \mathrm{Nb})_{6} \mathrm{Ce}, \mathrm{La}, \mathrm{Y}, \mathrm{Ga}, \mathrm{Li}\right)_{8}\left(\left((\mathrm{Cu}, \mathrm{V})_{6} \mathrm{Cr}, \mathrm{Ni}, \mathrm{Nb}\right)_{7} \mathrm{Co}, \mathrm{Pb}, \mathrm{Ag}, \mathrm{Ti}, \mathrm{Be}, \mathrm{Sc}, \mathrm{Ba}\right)_{8}\right.
$$

w interacjach najniższych ujawnia się parageneza $\mathrm{Cu}$ i V. Asocjację tę można tłumaczyć wpływem związków organicznych, z którą mogą być powiązane chalkofilne $\mathrm{Pb}$ i Ag, grupujące się w interacji wyższej.

W iłach rudnych strefy płycizny morskiej zauważa się bardzo ścisły związek ( $r>0,9)$ pomiędzy $\mathrm{Nb}$ i $\mathrm{Yb}, \mathrm{z}$ którymi $z$ kolei powiązane są $(r>0,75) \mathrm{Cr}$, Mo i Y. W ścisłym związku pozostają również $\mathrm{Mn}$ i $\mathrm{Cu}$ oraz szereg $\mathrm{Sn}-\mathrm{Ga}-\mathrm{Ni}$. Zgodnie $\mathrm{z}$ formułą korelacji wielokrotnej ścisły związek występuje pomiędzy $\mathrm{Nb}, \mathrm{Yb}$ i $\mathrm{Cr}$, a także $\mathrm{Mn}$ i $\mathrm{Cu}$

$\left(\left(\left(\left((\mathrm{Nb}, \mathrm{Yb})_{2} \mathrm{Cr}\right)_{3} \mathrm{Y}, \mathrm{Mo}\right)_{4} \mathrm{Be}\right)_{5} \mathrm{La}, \mathrm{Li}, \mathrm{Pb}, \mathrm{Ag}\right)_{6}\left(\left((\mathrm{Ce}, \mathrm{V})_{4} \mathrm{Ni}, \mathrm{Sn}, \mathrm{Mn}, \mathrm{Ga}, \mathrm{Sc}\right)_{5} \mathrm{Ti}, \mathrm{Zr}, \mathrm{Ba}, \mathrm{Co}, \mathrm{Cu}\right)_{6}$.

Złożony obraz współzależności pierwiastków śladowych obserwuje się w rudnych iłach przybrzeżnej strefy płycizny morskiej. Ujawniono tu ścisły związek $\mathrm{Mn}$ z Y ( $r>0,9)$, z którymi współwystępuje Ag $(r>0,75)$. Porównywalne związki istnieją w szeregu $\mathrm{Nb}-\mathrm{Zr}-\mathrm{V}$ i w wielokącie $\mathrm{Pb}-\mathrm{Co}-\mathrm{Ni}-\mathrm{Cr}-\mathrm{La}-\mathrm{Li}-\mathrm{Sn}-\mathrm{Yb}-\mathrm{Ga}$. Z formuly korelacji wielokrotnej

$$
\left(\left(\left((\mathrm{Pb}, \mathrm{Ni})_{3} \mathrm{Co}, \mathrm{Yb}, \mathrm{Ga}, \mathrm{Li}\right)_{4} \mathrm{Sn}, \mathrm{Cr}, \mathrm{Be}, \mathrm{Se}, \mathrm{La}\right)_{5} \mathrm{Ba}\right)_{6}\left(\left((\mathrm{Ag}, \mathrm{Mn}, \mathrm{Y}, \mathrm{Zn})_{4} \mathrm{Cu}, \mathrm{Nb}\right)_{5} \mathrm{Mo}, \mathrm{Ti}, \mathrm{Ce}\right)_{6}
$$

wynika wniosek o ścisłym związku Mn, Ag, Y, Zr z Cu, Nb i V, a także z Ti i Ce.

Najdokładniej zbadanymi i typowymi wśród wychodni rud $\mathrm{Cu}$ są obszary Łojewa, Jabłonowa, Nadwórnej, Kałusza, Delatyna ${ }^{14}$.

Obszar Łojewa położony jest na północno-wschodnim skraju miejscowości Delatyn (skały rudne ujawniono tu w lewym stoku doliny rzeki Prut i Łojewa, dopływów Latowiec i Olchowiec). Wydzielić można 4 horyzonty miedzionośne; minera-

\footnotetext{
${ }^{14}$ Według niepublikowanych informacji W. Girnego i W. Waszczenki.
} 
lizacja miedzionośna lokalizuje się w piaskowcach deltowych i iłach zawierających węglisty detrytus roślinny.

Horyzont pierwszy mieści się w części dolnej warstwy środkowej. Według danych geofizycznych ciało rudne występuje $w$ warstwie na głębokości $450 \mathrm{~m}$, jego miąższość wynosi 3-3,5 m, a Cu o zawartości około $0,15 \%$ na miąższości $1 \mathrm{~m}$.

Horyzont drugi występuje na głębokości $70-75 \mathrm{~m}$, stratygraficznie wyżej od pierwszego. Miąższość ciała rudnego ocenia się na $1,2 \mathrm{~m}$, a zawartość $\mathrm{Cu}-0,32 \%$, $\mathrm{Pb}-0,1 \%$ na miąższości $0,6 \mathrm{~m}$. Rozległość ciała rudnego ocenia się na nie mniej niż $100-150 \mathrm{~m}$.

Horyzont trzeci ujawnia się na lewym brzegu rzeki Prut. Jego miąższość wynosi od $0,2-0,5 \mathrm{~m}$, rzadko $1 \mathrm{~m}$. Zawartość $\mathrm{Cu}$ w ciele rudnym wynosi $1,25 \%$ na miąższości $1 \mathrm{~m}$. Mineralizacja miedzionośna tworzy tu soczewki i plamy o nieregularnej formie. Dostrzec tu również można drobne wrostki Au i Ag. Według danych geofizycznych opisywany horyzont sięga głębokości $250 \mathrm{~m}$, przy szerokości $40 \mathrm{~m}$.

Horyzont czwarty występuje w pokrywie warstwy środkowej. Ciało rudne charakteryzuje się niejednolitą miąższością formy płytowej, ze zwężeniami i zgrubieniami, niekiedy rozpadając się na szereg soczewek o rozmiarach $0,1-0,3 \mathrm{~m}$, rozciągniętych od 1-2 do 2-7 m. Ciało rudne występuje tu w części dolnej osadów deltowych. Miąższość ciała waha się od 0,5 do 4,8 $\mathrm{m}$. Zawartość Cu mieści się w szerokim przedziale wartości - od dziesiętnych części procenta po $15,9 \%$.

Według danych $\mathrm{z}$ badań geofizycznych czwarty horyzont występuje na głębokości $600 \mathrm{~m}$ i ma szerokość $40 \mathrm{~m}$.

Obszar Jabłonów ulokowany jest w międzyrzeczu rzek Nasarad - Dubowy. Wydziela się tu 3 horyzonty miedzionośne o miąższości od 4,5 do $12-20 \mathrm{~m}$.

Horyzont pierwszy występuje w dolnej części warstwy środkowej. Odsłonięcia rud miedzi są tu niejednolite na całej powierzchni, wyodrębniając się $w$ postaci soczewek o miąższości do $1 \mathrm{~m}$ i długości w granicach kilku metrów. Zawartość miedzi wynosi $0,15 \%$, przy miąższości $0,5 \mathrm{~m}$.

Horyzont drugi charakteryzuje się miąższością $10-20 \mathrm{~m}$. Ciało rudne jest niejednolite co do miąższości. Najintensywniejsza mineralizację dostrzec można w „soczewkach” wzbogaconych detrytusem roślinnym. Miążzość takich „soczewek" wynosi $0,2-0,3 \mathrm{~m}$, a rozległość warstw do $1-2 \mathrm{~m}$. W przestrzeni pomiędzy „soczewkami” występują drobne, rozproszone wrostki malachitu. Intensywność mineralizacji zmienia się znacznie od spagu ku stropowi warstwy rudonośnej. Zawartość $\mathrm{Cu}$ wynosi $0,3 \%$, przy miąższości $4 \mathrm{~m}$. Oprócz miherałów $\mathrm{Cu}$ obecne są tu galena i sfaleryt.

Horyzont trzeci występuje w części górnej warstwy środkowej. Mineralizacja $\mathrm{Cu}$ w piaskowcach zlokalizowana jest na kilku poziomach, od spagu po strop, w postaci soczewek o małej miąższości $(0,1-0,2 \mathrm{~m})$ i przewarstwień bogatych w metale i drobne rozproszone wrostki malachitu. Zawartość miedzi w piaskowcach waha się od 0,03 do $0,63 \%$ i wynosi średnio $0,2 \%$. 
Oprócz opisanych wyżej horyzontów rudonośnych w granicach badanego obszaru zauważono jeszcze kilka warstw iłów szarych i soczewek piaskowców ze zmineralizowaną $\mathrm{Cu}$.

Iły miedzionośne występują przeważnie jako formy o małej miąższości $(0,2-$ $0,3 \mathrm{~m}$ ), rzadko osiagając wielkość rzędu $0,7-1,0 \mathrm{~m}$. Zawartość $\mathrm{Cu}$ w iłach waha się od 0,05 do $0,8 \%$.

Obszar Nadwórna znajduje się pomiędzy rzekami Bystrzyca Nadwórniańska i Bystrzyca Sołotwińska. Wydzielić tu można 3 horyzonty rudonośne (fot. 4).

Pierwszy znajduje się w części dolnej warstwy środkowej. Miąższość horyzontu wynosi $25 \mathrm{~m}$, przy średniej zawartości Cu 0,57\% i Ag-40-63 g/t. Został on stwierdzony dzięki odwiertowi na głębokości $72-79 \mathrm{~m}$. Zawartość $\mathrm{Cu}$ wynosi $1,95 \%$, przy miąższości $0,5 \mathrm{~m}$. Według danych geofizycznych pierwszy horyzont ma długość do $2200 \mathrm{~m}$ i szerokość $140 \mathrm{~m}$.

Horyzont drugi charakteryzuje się miąższością $1 \mathrm{~m}$; średnia zawartość Cu wynosi $0,2 \%$ i więcej.

Trzeci horyzont miedzionośny mieści się w części górnej warstwy środkowej. Miąższość zmineralizowanej strefy piaskowca wynosi $1 \mathrm{~m}$, zawartość $\mathrm{Cu}-0,2 \%$, $\mathrm{a} \mathrm{Pb}-0,15 \%$. Na tym terenie dostrzec można punkty mineralizacji, w których minerały zawierające $\mathrm{Cu}$ występują $\mathrm{w}$ szarych iłach płytkomorskich lub przybrzeżnomorskich. Miąższość stref rudnych waha się od 0,1 do $0,5 \mathrm{~m}$. Zawartość $\mathrm{Cu}$ wynosi od 0,1 do $2 \%$. Dostrzega się tu także podwyższoną zawartość $\mathrm{Ag}$ (do $100 \mathrm{~g} / \mathrm{t}$ ).

Obszar Kałusz występuje w międzyrzeczu rzek Łomnicy i Łukwy. W środkowej warstwie produktywnej notuje się 3 horyzonty miedzionośne.

Pierwszy odsłania się w łożysku strumienia Bereznycze. Mineralizacja Cu występuje w spągu warstwy piaskowca deltowego. Miąższość ciała rudnego wynosi $6,1 \mathrm{~m}$, przy średniej zawartości Cu $0,18 \%$.

Miąższość ciała rudnego drugiego horyzontu miedzionośnego ocenia się na $1 \mathrm{~m}$, a zawartość Cu na $0,975 \%$.

Trzeci horyzont rudny występuje w części górnej warstwy środkowej. Miąższość części rudonośnej piaskowca wynosi $0,4 \mathrm{~m}$, a zawartość $\mathrm{Cu}-0,32 \%$. W granicach badanego obszaru odnotowano jeszcze dwa punkty mineralizacji $\mathrm{Cu}$.

Obszar Delatyn położony jest pomiędzy miejscowościami Delatyn i Strymba. W jego granicach ujawniono szereg anomalii geofizycznych i wykonano odwierty, które ujawniły w warstwie środkowej piaskowca punkty wzbogacone o minerały miedzionośne (zawartość Cu od 0,01 do 0,03\%).

III. Na obszarze karpacko-bałkańskim, w tym i metamorficznym kompleksie rachowskim, wyznaczono kilka wielkich pokładów formacji miedziowo-pirytowej okresu alpejsko-proterozoicznego. Typowymi reprezentantami dawnych pokładów 
miedziowo-pirytowych okresu przedalpejskiego poza granicami Ukrainy są: Smolnik (Czechy), Belan (Rumunia), Bor (Jugosławia). Pokłady tego typu na terenie Ukrainy znajdują się w rachowskim kompleksie metamorficznym ${ }^{15}$ (ryc. 2). Według danych geologiczno-mineralogicznych są one pokrewne wyżej wspomnianym złożom, szczególnie pokładom z Belan. W rachowskiej wychodni formacji miedziowo-pirytowej, w warstwach dyłowieckich, zbliżonych wiekiem do warstw Tulgesz pokładu Belan, podstawowym komponentem jest miedź, której zawartość w masywnych rudach sięga $12-15 \%$. Skład tych rud jest złożony - podstawowym minerałem rudnym jest tu chalkopiryt. W ilościach podrzędnych notuje się sfaleryt, galenę i sole siarczanowe. Wymienione pokłady rudne sa jeszcze niedostatecznie zbadane. Wcześniejsze badania geologiczne przeprowadzone przez N. Szyrinbekowa pozwalają na wytypowanie kilku obszarów z wychodniami napowierzchniowymi rud miedziowo-pirytowych w rejonie miejscowości Rachów, gdzie występują w dolinach prawych dopływów rzeki Cisy. Maksymalna miąższość warstw rudnych wynosi 5-6 m, długość zaś 100-120 m. Oddzielne bryły warstw rudnych spotyka się w łożyskach potoków ${ }^{16}$. Monolity rudne o zbliżonym składzie mineralnym i miąższości do $2 \mathrm{~m}$, rozlokowane na powierzchni terenu, spotyka się w pobliżu miejscowości Kosowska Polana (na północ od Łucza, $16 \mathrm{~km}$ od Rachowa). Na przełęczy pomiędzy Rachowem i Kosowską Polaną ujawniają się na powierzchni również odsłonięcia rud polimetalicznych (rejon starych sztolni).

W badaniach geochemicznych ważnym wskaźnikiem jest obecność znacznych zawartości $\mathrm{Ag}$ (do $70 \mathrm{~g} / \mathrm{t}$ ), Au (do $5 \mathrm{~g} / \mathrm{t}$ ) i Pd $(0,1 \%$ ). Nie stwierdzono natomiast obecności Sb i Bi.

Typowym przykładem składu chemicznego (\%) rudy miedziowo-pirytowej jest wzorzec N5 (analiza spektralna): $\mathrm{Mn}-0,03, \mathrm{Ni}-0,005, \mathrm{Co}-$ brak, Ti - 0,001. V $<0,001, \mathrm{Cr}-0,001, \mathrm{Mo}-0,0003$, $\mathrm{Hf}-$ nie ust., $\mathrm{Nb}-0,001, \mathrm{Cu}>10, \mathrm{~Pb}-0,001, \mathrm{Ag}$ $-0,005, \mathrm{Y}-0,001, \mathrm{Au}-0,0003$. Brak tu takich pierwiastków, jak: Zn, Sn, Ge, Ga, $\mathrm{Be}, \mathrm{Yb}, \mathrm{Li}, \mathrm{Ba}, \mathrm{As}, \mathrm{Zr}$, Ta.

W rozwoju i formowaniu się podobnego typu złóż miedziowo-pirytowych należy wyróżnić kilka etapów: początkowy - przedrudny, powiazzany z magmatyzmem geosynklinalnym typu spilitowo-diabazowego, kiedy to tworzą się warstwowe ciała rudne o drobno rozproszonym rozkładzie minerałów. Następny etap charakteryzuje się przegrupowywaniem pierwiastków rudnych. Na ostatnim etapie, po zakończeniu magmatyzmu o kwaśnym składzie (riolity), zachodzi późniejsze różnicowanie się złóż rudnych pochodzenia wulkanicznego, aż do tworzenia się wystapień rudnych typu żylnego poza granicami rozlokowania rud pierwotnych. Wychodnie rud miedzi w rachowskim kompleksie hutniczym są najsłabiej zbadane spośród wychodni znanych na terenie Ukrainy zachodniej i wymagają w przyszłości specjalistycznych badań geologiczno-geochemicznych.

\footnotetext{
${ }^{15}$ Obwód Zakarpacki, rejon Rachowski.

${ }^{16}$ Na przykład w środkowym biegu Strumienia Połońskiego.
} 
IV. Miedź rodzima, jako potencjalny surowiec dla metalurgii nieżelaznej w okresie istnienia kultury trypolskiej, jest dosyć dobrze rozpoznana na terenie Wołynia, gdzie napotyka się ją w bazaltach i tufach ciągnących się szerokim pasmem w kierunku północnym i północno-zachodnim. Długość tego pasma wynosi około $125 \mathrm{~km}$, przy szerokości od 14 do $22 \mathrm{~km}$. Bazalty rozlokowane są w granicach pęknięcia tektonicznego o tej samej długości. Specyficzną cechą ich rozmieszczenia jest formowanie się niewielkich obszarów, w których bazalty występują w postaci pokrywy przeławicającej się z tufitami. Maksymalna miąższość pokrywy bazaltowej wynosi ponad $40 \mathrm{~m}$. Dotychczas znany jest szereg odkrywek, gdzie ujawniła się pokrywa bazaltowa: Rafałówka, Janowa Dolina, Dowhe Pole, Berestowiec, stara kopalnia w miejscowości Wielki Mydzk i niewielkie wyrobiska w innych punktach (fot. 5, 6).

Bazalty Wołynia uważa się za utwory platformowe typowej formacji trappowej. U góry bazalty te przykryte są pokrywą skał osadowych paleogeńskiego wypiętrzenia turonu $\left(\mathrm{Cr}_{2} \mathrm{t}\right)$; zajmują one dużą powierzchnię. Warstwy osadowe wypiętrzenia cenomańskiego $(\mathrm{Cr} \mathrm{cm})$ występują w postaci niewielkich skupisk.

Osady paleogeńskie obecne w północnej części strefy, reprezentowane są przez warstwy kijowskie $\left(\mathrm{Pg}_{2} \mathrm{kv}\right)$. Szczególnie w kopalni Rafałówka występują one na bazaltach i złożone są z wapieni o małej miąższości. Osady neogeńskie składają się ze skał pokładu sarmackiego $\left(\mathrm{N}_{1} \mathrm{~S}\right)$. Wychodzą one na powierzchnię w rejonie miejscowości Wielki Mydzk, na południe od Berestowca. Charakterystyczna pod tym względem jest kopalnia Rafałówka (fot. 5). Tu, poniżej gleby współczesnej, występuja paleogeńskie wapienie o małej miąższości (do 1,5-2 m), z wkładkami utworów krzemionkowych (fot. 7). Nieznaczna głębokość zalegania krzemieni mogła sprzyjać ich wykorzystaniu w odległych epokach historycznych, dla potrzeb ludności pradziejowej. Paleogeńskie wapienie występują bezpośrednio na bazaltach, które zaliczają się do ryfejskiego kompleksu dajkowo-efuzywnego; ich wiek bezwzględny ocenia się na około $600 \mathrm{mln}$ lat.

W górnej części profilu bazaltów występuja typowe cechy strefy utlenienia, tworzące skorupę wietrzeniową. W różnych kopalniach jej miąższość jest zmienna. Typ skorupy wietrzeniowej można zaliczyć do otwartego, ponieważ proces wietrzenia narusza tylko części górne pokrywy bazaltowej, a jej miąższość waha się od 1,5 do $5 \mathrm{~m}$. Niekiedy bazalty wychodzą na powierzchnię. Charakterystyczną cechą mineralogiczną strefy utlenienia bazaltów jest obecność seladonitu, nadającego bazaltom wyraźną zieloną barwę.

W bazaltach Wołynia obecność miedzi rodzimej została stwierdzona i po raz pierwszy zbadana przez polskich geologów, którzy dokładnie ją opisali ${ }^{17}$. Według oceny S. Małkowskiego ogólne zasoby miedzi w Wielkim Mydzku wynoszą

${ }^{17}$ Małkowski 1931, s. 384-402; 1933, s. 352-361; Krajewski 1935, s. 407-415; Kowalski 1936, s. 316-328; Wojciechowski 1939, s. 401-409. 
$2500 \mathrm{~kg}$. Wielkie okazy miedzi rodzimej znajdowano w różnych czasach w kopalniach w miejscowościach Rafałówka, Dowhe Pole, Żyrycze, Janowa Dolina i Hutwyń. Waga okazów miedzi rodzimej waha się od 100 do $800-900$ g. Okazy o mniejszej wadze można spotkać na całym terytorium występowania bazaltów (fot. 8). Miedź rodzima pokryta jest czasami cienką błonką malachitu lub kuprytu, a w rzadkich przypadkach - azurytu. W różnych kopalniach miedź samorodna ma odmienne właściwości morfologiczne. W rejonie miejscowości Wielki Mydzk spotyka się je w postaci utworów nieregularnie zaokraglonych. W skałach w miejscowości Dowhe Pole wypełnia ona pęknięcia, niekiedy występuje w postaci blaszek i utworów dendropodobnych lub w postaci blon i skorup, drobnych inkluzji, gęstych wrostków drobnoziarnistych w podstawowej masie bazaltu.

Miedź rodzima $w$ niewielkich ilościach występuje w szkliwie wulkanicznym bazaltów i tufów. Oprócz niej w kompleksie bazaltowym występują nieznaczne ilości minerałów siarczkowych. Wśród tych ostatnich należy wymienić chalkozyn występujący w paragenezie $\mathrm{z}$ miedzią rodzimą. Minerał ten jest odkrywany w postaci niedużych soczewek lub żyłek. Chalkopiryt tworzy skupiska drobnych kryształów lub żyłek, które można zauważyć w bazaltach w miejscowościach Janowa Dolina i Hutwyń. Kupryt jako minerał strefy utlenienia występuje w postaci cienkich błon i blaszek po miedzi rodzimej. W niektórych przypadkach można zauważyć zastępowanie kuprytu malachitem.

Malachit i azuryt występują w postaci nalotów lub powłok na powierzchni miedzi rodzimej. Minerały są obecne w bazałtach w miejscowościach Wielki Mydzk

Tabela 8

Wyniki analizy spektralnej miedzi rodzimej Wolynia (\%)

Table 8

Volyn cuprous rocks spectrum analysis results (\%)

\begin{tabular}{|l|l|l|l|l|l|l|l|l|l|l|}
\hline $\begin{array}{l}\text { Pierwiastki } \\
\text { chemiczne }\end{array}$ & $\mathrm{Nr} 1$ & $\mathrm{Nr} 2$ & $\mathrm{Nr} 3$ & $\mathrm{Nr} 4$ & $\mathrm{Nr} 5$ & $\mathrm{Nr} 6$ & $\mathrm{Nr} 7$ & $\mathrm{Nr} 8$ & $\mathrm{Nr} 9$ & $\mathrm{Nr} 10$ \\
\hline $\mathrm{Fe}$ & 1,5 & 1,5 & 1 & 1,5 & 1 & 2 & 0,9 & 1,5 & 0,3 & 1,3 \\
$\mathrm{Si}$ & 1 & 0,7 & 0,8 & 1,5 & 0,003 & 1 & 1 & 1 & 0,5 & 1 \\
$\mathrm{Mg}$ & 0,3 & 0,1 & 0,4 & 1 & 0,03 & 3 & 0,1 & 0,15 & 0,2 & 0,6 \\
$\mathrm{Mn}$ & 0,03 & 0,03 & 0,2 & 0,3 & - & 0,1 & 0,003 & 0,004 & 0,001 & 0,01 \\
$\mathrm{Ca}$ & 0,3 & 0,2 & 1 & 1 & - & 0,1 & 0,001 & - & 0,5 & 0,2 \\
$\mathrm{Al}$ & 0,5 & 0,4 & 0,3 & 1 & 0,002 & 1 & 0,01 & 0,1 & 0,4 & 0,6 \\
$\mathrm{Na}$ & - & - & - & 1 & - & - & & & - & - \\
$\mathrm{Ag}$ & 1 & 1 & 1 & 0,2 & 0,08 & 0,1 & 0,25 & 1 & - & 1 \\
$\mathrm{Cr}$ & 1 & 1 & 1 & 1 & 1 & 1 & 1,2 & 1,2 & 1 & 0,01 \\
$\mathrm{~Pb}$ & - & - & & 0,0001 & 0,0001 & 0,0001 & 0,005 & - & - & - \\
$\mathrm{Sn}$ & - & - & - & - & - & - & 0,006 & - & - & - \\
\hline
\end{tabular}

Odcinki wystapień rudnych: Rafałówka (Nr 1-8), Zyrycze (Nr 9), Dowhe Pole (Nr 10). 
i Janowa Dolina. W ten sposób za podstawowy surowiec rudny można uważać miedź rodzimą której znaleziska występują w górnej części utlenionej warstwy bazaltowej. Podczas prac terenowych pobrane zostały próbki miedzi rodzimej z trzech obszarów (Rafałówka, Dowhe Pole, Żyrycze). Obszar miejscowości Rafałówka jest jednym $z$ najbogatszych $w$ miedź rodzimą. Badania składu chemicznego próbek miedzi rodzimej (tab. 8) wykazały podwyższoną zawartość $\mathrm{Fe}, \mathrm{Ag}$ i $\mathrm{Cr}$. Pierwiastki te znajdują się w miedzi jako domieszka strukturalna i mogą pełnić funkcję cechy korelacyjnej przy identyfikacji składu chemicznego miedzi rodzimej i wyrobów miedzianych kultury trypolskiej na terenie zachodniej Ukrainy. Zawartość pierwiastków głównych, z wyjątkiem Fe, może ulegać zmianie i nie jest charakterystyczna, ponieważ są one obecne jako domieszki mechaniczne zagarnięte ze skał zawierających (w procesie ruchu pierwotnego) roztwór hydrotermalny. Miedź rodzima charakteryzuje się nieznaczną ilością $\mathrm{Pb}$ lub jego zupełnym brakiem. Korelacja wyników analizy spektralnej jej próbek z badań wcześniejszych i nowych znalezisk pozwala na wyróżnienie, jako szczególnej cechy geochemicznej, nieobecności takich pierwiastków, jak: $\mathrm{Ni}, \mathrm{Zn}, \mathrm{Sn}, \mathrm{Sb}$. Stale nieobecne są także As i Bi.

Miedź rodzima z obszaru Dowhe Pole, stosownie do zawartości podstawowych pierwiastków głównych i śladowych, odpowiada miedzi z obszaru Rafałówka, podczas gdy miedź z obszaru Żyrycze zawiera mniejszą ilość domieszek, co świadczy o jej wysokiej czystości. Według danych E. Lazarenki i innych ${ }^{18}$ miedź z obszaru Wielki Mydzk charakteryzuje się największą czystością na całym świecie.

Dzisiejszy stan naszej wiedzy o miedzi rodzimej Wołynia pozwala przypuszczać, że metal ten mógł być wykorzystywany w dawnych epokach historycznych jako surowiec do produkcji wyrobów miedzianych. Sprzyjało temu zaleganie miedzi rodzimej blisko powierzchni, w skorupie wietrzenia bazaltów oraz spora waga odłamków. Ocena skali wykorzystania tego surowca jest na razie przedwczesna, z powodu niedostatku badań metalowych zabytków archeologicznych, znalezionych w obrębie obszarów rozwoju bazaltów miedzionośnych oraz poza strefą ich koncentracji. Jednakże geolog polski S. Małkowski jeszcze w latach 1928-1930 ujawnił w rejonie miejscowości Wielki Mydzk (obwód równeński) dawne wyrobiska w postaci wąskich wykopów, w których wypełniskach odnalazł kamienne siekiery i fragmenty naczyń kultury ceramiki sznurowej ${ }^{19}$. Dane te i wyniki analizy spektralnej serii wyrobów miedzianych kultury ceramiki sznurowej z Wołynia pozwoliły N. Ryndinej mówić o ,szczególnej” roli miedzi wołyńskiej w miejscowej produkcji ${ }^{20}$.

Nasze badania wyrobów miedzianych kultury trypolskiej ( $z$ osiedla Hłyboczek w obwodzie tarnopolskim i cmentarzyska sofijewskiego w obwodzie kijowskim) wykazały znaczne podobieństwo ich składu chemicznego do wołyńskiej miedzi rodzimej.

\footnotetext{
${ }^{18}$ Lazarenko i inni 1960, s. 509.

${ }^{19}$ Małkowski 193!, s. 400.

${ }^{20}$ Ryndina 1980 , s. 24-41.
} 
W dalszych badaniach miedzi rodzimej Wołynia należałoby zwrócić uwagę na dobór próbek z obszarów najsłabiej zbadanych, a także na prace eksperymentalne powiązane $\mathrm{z}$ poznaniem składu makro- i mikrodomieszek $w$ metalu naturalnym i po jego stopieniu, w próbkach czystego metalu rodzimego i utlenionego, pokrytego „koszulką” z minerałów charakteryzujących procesy wietrzenia skał.

\section{PODSUMOWANIE I WNIOSKI}

Wyniki terenowych badań geologicznych na terenie Przykarpacia i Naddniestrza potwierdziły obecność $\mathrm{Cu} w$ wychodniach skał rudnych pochodzenia osadowego, w których tylko gdzieniegdzie zachowały się odcinki $\mathrm{z}$ utlenionymi rudami siarczkowymi. Wniosek ten daje podstawę twierdzeniu o ich intensywnym użytkowaniu w przeszłości, przy czym zawartość minerałów miedzi mogła być zupełnie wystarczająca do uzyskania metali kolorowych. Doniesienie geologów o znalezieniu w rudach utlenionych niewielkich okazów miedzi samorodnej jest potwierdzeniem istnienia w przeszłości procesów utleniania na wielką skalę i przydatności warstw rudonośnych do celów metalurgicznych $w$ okresie funkcjonowania kultury trypolskiej.

Parametry geochemiczne najbogatszych rud miedzionośnych, znanych dotychczas z terenów Naddniestrza i Przykarpacia, świadczą o tym, że metale kolorowe otrzymane przez wytapianie tych rud powinny mieć skład chemiczny właściwy dla miedzi o różnych zawartościach domieszek $\mathrm{Pb}$, rzadziej $\mathrm{Zn}$, a także brązu ołowiowego.

W celu ustalenia powiązań składu chemicznego rud i metali należałoby przeprowadzić badania metalowych zabytków archeologicznych z południowej części obwodu tarnopolskiego i północno-wschodniej części obwodu iwano-frankowskiego (dawnego stanisławowskiego), znajdujących się w strefie rozwoju rud miedzi.

Otrzymane dane składu chemicznego rodzimej miedzi Wołynia pozwoliły ustalić chemiczne kryterium ich identyfikacji z miedzianymi wyrobami kultury trypolskej, których podstawowym wskaźnikiem jest $\mathrm{Ag}$ i Cr, a z pierwiastków głównych $-\mathrm{Fe}$.

Wychodnie rud miedziopirytowych i polimetalicznych w górskich okolicach Karpat Ukrainskich wymagaja gruntowniejszych badań geologiczno-geochemicznych, w tym oceny zasobów rud i przeprowadzenia prac eksperymentalnych w celu uzyskania z nich metali kolorowych.

Dlatego też jako najbardziej obiecujące kierunki przyszłych badań archeologicznych można określić:

1. Dalsze rozszerzanie i precyzowanie naszej wiedzy o pokładach rud miedzionośnych i miedzi rodzimej na terenie Ukrainy Zachodniej i rejonów przylegających (w tym krajów ościennych) - jako bazy surowcowej dla dawnej produkcji metali kolorowych. 
2. Badania składu chemicznego wyrobów miedzianych i miedziopochodnych epoki chalkolitu Ukrainy prawobrzeżnej i wschodniej Polski, a jednocześnie wypracowanie niezawodnych metod związku wstecznego, w relacji: wyrób miedziany źródło surowca; wyrób miedziopochodny - źródło surowca.

3. Poszukiwanie i kompleksowe badania archeologiczno-geochemiczne zabytków dawnej metalurgii na terenie Przykarpacia i Karpat.

Przektad z jezyka rosyjskiego: Stawomir Pietrzak i Robert Sokotowski

\section{BIBLIOGRAFIA}

Andreyeva-Grigorovich A.S., Stupnickiy V.M.

1976 Nannoplankton nizhnemelovykh otlozheniy yugo-vostochnovo Predkarpatva, „Geologicheskiy Zhurnal", t. 36, s. 139-143.

B ir i y u leva L.V., B iriyuliev A.E., Kachor L.D.

1966 Mineralogii nizhnedevonskikh medictykh peschanikov Pridnestrovya (voprosy mineralogii ostadochnkh pbrazovanii), Lvov, s. 159-166.

Burov V.S., G I u sh ko V.V., P is hvanova L.S.

1971 Neogenovye otlozheniya Pridkarpatskogo progiba (Geologicheskoye stroyeniye i goryuchie iskopayemye Ukrainskikh Karpat), Lvov, s. 42-54.

Czernykh E.N.

1966 Istoriya drevneyshey metallurgii Vostochnoy Evropy, Moskva.

1978 Gornoye delo i metallurgiya v drevneyshey Bolgarii, Sophiya.

1989 Metall i drevnye kultury: uzlovye problemy issledovaniya, (w:) Estestvennonauchnye metody varkheologii, Moskva, s. 14-30.

Geologicheskaya istoriya

1993 Geologicheskaya istoriya territorii Ukrainy, Paleozoy, Kiev.

K l o c h k o V.I.

1994 Metallurgicheskoye proizvodstvo v eneolite - bronzovom veke, (w:) Remieslo epokhi eneolita - bronzy na Ukraine. Kiev, s. 96-132.

Kowalski M.

1936 Wyniki rozbioru chemicznego bazaltów i skal z nimi zwiqzanych z Wotynia, w poszukiwaniu śladów miedzi, Biuletyn P.I.G., t. 44, s. 316-328.

Krajewski R.

1935 Ślady miedzi rodzimej w Janowej Dolinie, Biuletyn P.I.G., t. 42, s. 407-415.

Krasheninnikov V.A.

1971 Stratigraphiya miocenovykh otlozheniy Sredizemnomorya po phoraminipheram. Trudy Geologicheskogo Instituta SSSR, Moskva.

Khrushchov D.P., Kompanec G.C.

1988 Litologiya galogennykh i krasnocvetnykh phomaciy Predkarpatya, Naukova Dumka, Kiev.

Khrushchov D.P., Nechaev U.A., Kardash V.G., Galin S.A.

1977 Mednoe orudenenye strtiphicirovannogo tipa $v$ otlozheniyakh, parageneticheski svyazanny$k h$ s solenosnymi phormacyami Ukrainy, Kiev. 
Lazarenko E.K., M a t kovski y O.I., Vinar O.M., Sha shy na V.P, G nalv G.M.

1960 Mineralogiya viverzhenikh kompleksiv Zakhidnoy Volini, Lvov.

Lazarenko E.K., Srebrodolski y B.I.

1969 Mineralogiya Podshlaya, t. 1, Lvov.

Lurye A.M.

1963 Medenosnost devonskikh krasnocvetov Pridnestrovya, Lvov.

Małkowski S.

1931 Z geologii Wotynia, „Rocznik Wołyński”, t. II, s. 384-402.

1933 Nowe wiadomości o występowaniu miedzi w dorzeczu Horynia., Biuletyn P.I.G, t. 36, s. $352-361$.

Narbutas V.V.

1984 Krasnocvetnye phormacii nizhnego devona Pribaltiki i Podolii, Vilnyus.

Nikiphorova O.I., Predtechenskiy N.N.

1972 Opornyj razrez silura i nizhnego devona Podolii, Moskva.

R y ndin a N.V.

1971 Drevneysheye metallobratyvayusheye proizvodstvo Vostochnoy Evropy, Moskva.

1980 Metall v kulturakh shnurovoy keramiki Ukrainskogo Predkarpatya, Podolii I Volyni, "Sovetskaya Arkheologiya", t. 3, s. 24-41.

1998 Drevneysheye metallobratyvayusheye proizvodstvo Yugo-Vostochnoy Evropy, Moskva, s. 16-18.

\title{
Spravochnik
}

1983 Spravochnik po litologii, Moskva.

Ste in inger F., Rog 1 F.

1982 Stratigraphic correlation of the Tethys - Paratethhys Neogene: Project 25 (Geological Correlation), Paris, s. 66-67.

Stratigraphiya USSR

1975 Stratigraphiya USSR, Naukova Dumka, t. 10, Kiev.

Venglinski y I.V., Gor e c k i y V.A.

1979 Stratotypy miocenovykh otlozheniy Volyno-Podolskoy plyty, Predkarpatskogo i Zakarpatskogo progibov, Kiev.

Woj c i e chowski I.

1939 Ślady miedzi $w$ serii osadów typu tufitów bazaltowych w Hancewiczach na Polesiu. Biuletyn P.I.G., t. 14, s. 401-409.

\section{BASSETS OF COPPER ORE IN WESTERN UKRAINE AS A RAW MATERIAL BASE OF COLOR METALLURGY IN THE PERIOD OF TRIPOLYE CULTURE}

\author{
Su $\mathrm{m} m$ ary
}

The objective of joint scientific investigations among the archaeologists and geologists-chemists is to determine the role of Western Ukrainian copper ore manifestations as possible raw material in nonferrous metal production during Tripolie culture stage.

The preliminary study of chemical composition of Tripolie culture hardware taken from Ternopol, Kiev and Cherkassy regional museums initiated the beginning of this work. The foundry forms findings from archaeological monuments near by the copper ores series outcrops in Prydnestrovie (Ivano- 
Frankovsk, Ternopol region) and Volhynia can serve as an important reason for the local ores exploitation benefit as well. Copper ore manifestation of different genesis and age in Western Ukraine were familiar to the ancient miners since they outcropped on day surface, and their oxidized height was rather significant.

The preliminary conclusion has been made on evidence derived from the materials on field expeditionary study carried out by the authors, and also by the factual data obtained before that copper ores by their chemical composition in modern exposures of Dnestr $r$. basin are close in the composition to a number of hardware from the archaeological monuments, by the example of Glybochok Bilche-Zolotoje. The chemical similarity of native copper from ancient Volhynia volcanogenic complexes to Tripolie stage copper from Kiev and Cherkassy regions has been fixed also.

The field study of copper ores formation natural sections in Western Ukraine has shown the today's absence of ore heights intensive oxidation sites. As a rule, the sections with malachite and atacamite weak development are observed. Modern sedimentary ore coppers oxidized heights can be the family likeness to ancient ones, which were used in non-ferrous metallurgy.

It is necessary to take into account the fact, that ores being high in copper content could be yielded during the mining above the millennium's period. Due to subsequent natural dynamic processes in ravines and on the river valley slopes, where the copper ore layers large outcrops took place, they were overlapped by thick sediment masses. The statements of geologists by whom the significant outcrops of copper ores with large native copper inclusions were observed even 10-15 years ago can be as example of the above mentioned. At present these outcrops are overlapped by deluvial deposits (Predcarpathie deposits).

As chemical composition of Predcarpathie modern oxidized copper ores shows, the copper content within is quite enough for metal copper producing. The experimental evidence provided by the metal melting from this ore have shown the capabilities of producing the metal from these ores wherein the chemical elements recrements as a whole can correspond to ore raw material.

Later on the missing information must be obtained of native copper chemical composition from Predcarpathie and Prydnestrovie sedimentary copper ore heights as the special literature sources pointed out. The performance of Volhynia native copper experimental melting will permit to establish geochemical criterion for Volhynia native copper identification with copper wares from archaeological monuments.

In connection with the further running of works on geology-geochemical study of rocks with copper metallization the reconstruction of ancient ore heights chemical composition has to be done taking in account the mineralogy-geochemical features of lithological rhythm modern complexes, and then it is essential to create a database on this ground. 